NASA/TM-2000-209443

\title{
Launch Vehicle Performance for Bipropellant Propulsion Using Atomic Propellants With Oxygen
}

Bryan Palaszewski

Glenn Research Center, Cleveland, Ohio 
Since its founding, NASA has been dedicated to the advancement of aeronautics and space science. The NASA Scientific and Technical Information (STI) Program Office plays a key part in helping NASA maintain this important role.

The NASA STI Program Office is operated by Langley Research Center, the Lead Center for NASA's scientific and technical information. The NASA STI Program Office provides access to the NASA STI Database, the largest collection of aeronautical and space science STI in the world. The Program Office is also NASA's institutional mechanism for disseminating the results of its research and development activities. These results are published by NASA in the NASA STI Report Series, which includes the following report types:

- TECHNICAL PUBLICATION. Reports of completed research or a major significant phase of research that present the results of NASA programs and include extensive data or theoretical analysis. Includes compilations of significant scientific and technical data and information deemed to be of continuing reference value. NASA's counterpart of peerreviewed formal professional papers but has less stringent limitations on manuscript length and extent of graphic presentations.

- TECHNICAL MEMORANDUM. Scientific and technical findings that are preliminary or of specialized interest, e.g., quick release reports, working papers, and bibliographies that contain minimal annotation. Does not contain extensive analysis.

- CONTRACTOR REPORT. Scientific and technical findings by NASA-sponsored contractors and grantees.
- CONFERENCE PUBLICATION. Collected papers from scientific and technical conferences, symposia, seminars, or other meetings sponsored or cosponsored by NASA.

- SPECIAL PUBLICATION. Scientific, technical, or historical information from NASA programs, projects, and missions, often concerned with subjects having substantial public interest.

- TECHNICAL TRANSLATION. Englishlanguage translations of foreign scientific and technical material pertinent to NASA's mission.

Specialized services that complement the STI Program Office's diverse offerings include creating custom thesauri, building customized data bases, organizing and publishing research results ... even providing videos.

For more information about the NASA STI Program Office, see the following:

- Access the NASA STI Program Home Page at http://www.sti.nasa.gov

- E-mail your question via the Internet to help@sti.nasa.gov

- Fax your question to the NASA Access Help Desk at 301-621-0134

- Telephone the NASA Access Help Desk at 301-621-0390

- Write to: NASA Access Help Desk NASA Center for AeroSpace Information 7121 Standard Drive Hanover, MD 21076 
NASA/TM-2000-209443

(2)

Launch Vehicle Performance for Bipropellant Propulsion Using Atomic Propellants With Oxygen

Bryan Palaszewski

Glenn Research Center, Cleveland, Ohio

Prepared for the

35th Joint Propulsion Conference and Exhibit

cosponsored by the AIAA, ASME, SAE, and ASEE

Los Angeles, California, June 20-24, 1999

National Aeronautics and

Space Administration

Glenn Research Center 
Available from

NASA Center for Aerospace Information 7121 Standard Drive

Hanover, MD 21076

Price Code: A03
National Technical Information Service 5285 Port Royal Road Springfield, VA 22100 Price Code: A03 


\title{
LAUNCH VEHICLE PERFORMANCE FOR BIPROPELLANT PROPULSION USING ATOMIC PROPELLANTS WITH OXYGEN
}

\author{
Bryan Palaszewski \\ National Aeronautics and Space Administration \\ Glenn Research Center \\ Cleveland, Ohio 44135
}

\begin{abstract}
Atomic propellants for bipropellant launch vehicles using atomic boron, carbon, and hydrogen were analyzed. The gross liftoff weights (GLOW) and dry masses of the vehicles were estimated, and the "best" design points for atomic propellants were identified. Engine performance was estimated for a wide range of oxidizer to fuel $(\mathrm{O} / \mathrm{F})$ ratios, atom loadings in the solid hydrogen particles, and amounts of helium carrier fluid. Rocket vehicle GLOW was minimized by operating at an $\mathrm{O} / \mathrm{F}$ ratio of 1.0 to 3.0 for the atomic boron and carbon cases. For the atomic hydrogen cases, a minimum GLOW occurred when using the fuel as a monopropellant $(\mathrm{O} / \mathrm{F}=0.0)$. The atomic vehicle dry masses are also presented, and these data exhibit minimum values at the same or similar $\mathrm{O} / \mathrm{F}$ ratios as those for the vehicle GLOW. A technology assessment of atomic propellants has shown that atomic boron and carbon rocket analyses are considered to be much more near term options than the atomic hydrogen rockets. The technology for storing atomic boron and carbon has shown significant progress, while atomic hydrogen is not able to be stored at the high densities needed for effective propulsion. The GLOW and dry mass data can be used to estimate the cost of future vehicles and their atomic propellant production facilities. The lower the propellant's mass, the lower the overall investment for the specially manufactured atomic propellants.
\end{abstract}

\section{NOMENCLATURE}

$\begin{array}{ll}\text { A } & \text { Fixed mass scaling parameter }(\mathrm{kg}) \\ \mathrm{Al} & \text { Aluminum } \\ \mathrm{B} & \text { Boron } \\ \mathrm{B} & \text { Propellant dependent mass scaling } \\ & \text { parameter }(\mathrm{kg} / \mathrm{kg} \mathrm{M}) \\ \mathrm{C} & \text { Carbon } \\ \mathrm{GLOW} & \text { Gross Lift Off Weight } \\ \mathrm{H} & \text { Atomic hydrogen } \\ \mathrm{He} & \text { Helium }\end{array}$

$\begin{array}{ll}\mathrm{H}_{2} & \text { Molecular Hydrogen } \\ \mathbf{I}_{\mathrm{sp}} & \text { Specific impulse (s) } \\ \mathrm{M}_{\mathrm{p}} & \text { Propellant mass (kg) } \\ \mathrm{NLS} & \text { National Launch System } \\ \mathrm{O} / \mathrm{F} & \text { Oxidizer to Fuel ratio, or Mixture } \\ & \text { ratio } \\ \mathrm{O}_{2} & \text { Oxygen } \\ \mathrm{wt} \% & \text { Weight Percent }\end{array}$

\section{INTRODUCTION}

Atomic propellants have great potential for increasing rocket specific impulse, and reducing the cost for access to space. With atomic propellants, the rocket specific impulse $\left(I_{s p}\right)$ can be increases many hundreds of seconds over oxygen/hydrogen rockets, thereby opening new and previously impossible opportunities in space access. Figure 1 depicts the gross liftoff weight (GLOW) reductions that are possible with atomic boron propellants (Ref. 1). While the potential for these propellants is great, they are not a near term solution for space transportation. Much research is needed to store the atoms successfully at high atom weight percent (wt $\%$ ) values for rocket and airbreathing propulsion. This paper describes the selection of the "best" design points for atomic fueled rockets, and the issues that must be addressed during their system design.

\section{PAYOFFS FOR ATOMIC PROPELLANTS}

Using high energy density materials (HEDM) as propellants, the cost of space access can be reduced for future airbreathing and rocket-powered space vehicles. Increasing the payload mass per flight, and/or reducing the complexity of vehicle operations enables the cost reductions. The ways to increase vehicle payload performance with advanced fuels are reducing the gross lift off weight (GLOW), reducing the dry weight, and reducing vehicle size due to increased fuel density, or increased specific impulse, or both. 
The costs of launching to Earth orbit are a major challenge to reducing in-space transportation costs. If the payload to orbit per flight were increased, the number of launches to effect missions is reduced. This reduction in launches and the attendant cost reductions are particularly important for missions to the outer Solar System, or any high-energy space mission. The effective mission travel time is also reduced, in that the reduced number of launches reduces the time for on-orbit assembly of large space vehicles. These time reduction analyses were conducted for human Mars missions (Ref. 2), and the results were impressive. The time to deliver payload to orbit, and ultimately to Mars, were reduced by many years using metallized gelled propellants, or $\mathrm{O}_{2} / \mathrm{H}_{2} / \mathrm{Al}$, with increases in $\mathrm{I}_{\text {sp }}$ of 10 seconds. New HEDM propellants can provide near term incremental benefits in increased specific impulse $\left(I_{s p}\right)$ that will save years of assembly costs for large space missions. Future far-term atomic HEDM propellants may deliver 100's of seconds of increased Isp over $\mathrm{O}_{2} / \mathrm{H}_{2}$ propulsion. This performance increase can translate into more compact space vehicles, with GLOW values that are up to 80 percent less than that of current launch vehicle designs. These GLOW reductions can be translated into hundreds of percents increases ( 264 to $360 \%$ with atomic hydrogen) in payload mass delivered to orbit. As an example, a $96,000-\mathrm{kg}$ payload can be increased to over $170,000 \mathrm{~kg}$ with $50-\mathrm{wt} \%$ boron, and to over $475,000 \mathrm{~kg}$ with a $50-\mathrm{wt} \%$ atomic hydrogen rocket. These payload increase cases can allow one heavy lift launch vehicle to deliver a complete human interplanetary space vehicle to orbit. This launch capability would save billions of dollars and many years of time by eliminating on-orbit assembly. When speed is essential, atomic propellants can ultimately open up the Solar System. from the ground up.

Using atomic propellants in aeronautical and space vehicles has many challenges, and their solutions will spring from both basic physics and engineering (Ref. 3-28). A current vision of the vehicle propellant design includes using solid particles of molecular hydrogen to store the atoms. The particles are then stored in liquid helium at 3-4 $\mathrm{K}$ temperatures. The liquid helium will also aid the flow of the atom-laden hydrogen particles. The challenges for these propellants include high rates of atom formation, stable storage of the atoms, and storage of the atoms in solid cryogenic hydrogen particles. To make an effective feed system, the vehicle will have to have ground support equipment to form millions of the solid cryogenic particles, and provide reliable flow of these particles from the propellant tank to the combustion or recombination chamber (Ref. 1). In addition, the temperature of the particles must remain at 3 to $4 \mathrm{~K}$ until they are to be used in the rocket combustion chamber, and be protected from the high heat fluxes typical of high-energy rocket engines.

\section{ATOMIC ROCKET VEHICLES}

Atomic rocket vehicles were designed using tankage and vehicle mass estimating codes (Ref. 1) and rocket performance analyses using the CET program (Ref. 29). Helium addition of 10-, 20-, and $40-\mathrm{wt} \%$ was computed to simulate the addition of a carrier fluid to aid the flow of solid hydrogen particles from the propellant tanks to the rocket engine (Ref. 1). Other assumptions regarding the selection of the atom wt \% loadings, and the fuel densities for the B, C, and $\mathrm{H}$ with varying helium addition $\mathrm{wt} \%$ values are discussed in Ref. 1. The general vehicle sizing assumptions are also provided in Ref. 1, and specific sizing assumptions for the higher $\mathrm{O} / \mathrm{F}$ bipropellant cases are discussed in the succeeding sections.

\section{Rocket Engine Performance}

Rocket performance estimates are provided in Figures 2 through 8 . The atom wt\% values were selected based on the results of Ref. 1. The boron level of $22-w t \%$ B and the carbon level 24-wt\% C represent reasonable extrapolations of what will be feasible with atomic storage in solid hydrogen. The $50-\mathrm{wt} \% \mathrm{~B}$ and $50-\mathrm{wt} \% \mathrm{C}$ represent design points were where the atomic vehicles' GLOW is comparable to or significantly reduced over the $\mathrm{O}_{2} / \mathrm{H}_{2}$ cases (Ref. 1). All of the atomic hydrogen cases were selected based on analyses that showed potential for GLOW reductions (Ref. 1). Currently, the best storage density of atomic $\mathrm{H}$ is much lower than 10$\mathrm{wt} \% \mathrm{H}$, and therefore much research is needed to demonstrate these storage wt\% levels. Current storage capabilities for atomic hydrogen are near 0.1-wt\%, and have no possibility of providing a propulsion system gain in GLOW or engine $I_{\mathrm{sp}}$. The atomic hydrogen cases are presented to illustrate what could be possible if breakthroughs in propellant technology were made. Though many of these rocket analyses represent future hopes for atomic propellants, the analyses show the place to select the best atomic propellant loadings for the "best" vehicle design with the lowest GLOW and lowest dry mass. These analyses also show what the possibilities are for payload increases for the rocket propellants. 
The sensitivity of the $I_{s p}$ to helium addition of 10-, 20-, and 40-wt\% helium was also computed. In the overall view, the Isp of the rocket engines was greatly reduced by the addition of helium at the low (0.0) $\mathrm{O} / \mathrm{F}$ ratio. At higher $\mathrm{O} / \mathrm{F}$ ratios, the higher density oxygen replaces a fraction of the less-dense fuel. By using oxygen, the overall vehicle volume and GLOW are reduced. The GLOW can be significantly reduced because lighter tankage is needed to contain the fuel and oxidizer. The lower engine $I_{\mathrm{sp}}$, along with higher oxidizer density, leads to a more mass efficient vehicle than the monopropellant vehicle. This bodes well for the higher $\mathrm{O} / \mathrm{F}$ ratio engine operation, and vehicle design, especially for the lower atom wt\% levels.

In Ref. 1, the rocket engine performance of the atomic engines was presented, and the effects of helium addition on the $I_{\mathrm{sp}}$ were shown to be small for the high atom storage, $50-w t \%$ cases. In many cases, and even with lower atom wt $\%$ values, the operation of the rocket engine at higher $\mathrm{O} / \mathrm{F}$ ratios (between 2.0 and 4.0) showed little reduction in engine $I_{\text {sp }}$ due to the effect of helium addition. This effect is important for delivering a low GLOW, and having a successful particle flow system. Previous analyses (Ref. 1) implied that, for monopropellant operation, the higher helium wt\% levels would never be beneficial for atomic rockets. Analyses for bipropellant operation has shown that in many cases, a very high $40-w t \%$ helium level may be used, and have a relatively small effect on increasing the GLOW.

Boron: The atomic $B$ engine $I_{s p}$ values were estimated for a $22-$ and $50-w t \%$ atom cases. For the $22-w t \%$ B engine, the maximum $I_{\mathrm{sp}}$ value is 518.9 seconds at an $\mathrm{O} / \mathrm{F}$ ratio of $0.5(00-\mathrm{wt} \% \mathrm{He})$. Adding the $40-\mathrm{wt} \%$ He to the $22-\mathrm{wt} \% \mathrm{~B}$ (at an $\mathrm{O} / \mathrm{F}=$ $0.5)$ reduced the $I_{s p}$ to 449 seconds. With the 50 -wt $\%$ case $(00-w t \% \mathrm{He})$, the engine $I_{\mathrm{sp}}$ is 651 seconds $(\mathrm{O} / \mathrm{F}=0.0)$, and the corresponding value with $40-\mathrm{wt} \% \mathrm{He}$ is 522 seconds.

The engine performance with atomic boron with $40-w t \%$ helium addition is very low at the low O/F ratios. Using the higher $O / F$ ratios, the engine performance was found to be much less sensitive to helium addition. Figures 2 and 3 show that at the $\mathrm{O} / \mathrm{F}$ ratios of 2 to 4 , the effect of helium addition is relatively small, and these data were used later to find the "best" design point for the atomic rocket vehicles. If there is a small effect of the helium addition on the engine $I_{s p}$, this fact can be used to ease the design challenges of the feed system. With a larger helium wt $\%$, there is a better chance to make the solid particle feed system successful.

At a 50-wt \% B loading (and 00-wt\% He), the maximal $I_{\mathrm{sp}}$ is 651.2 seconds, at an $\mathrm{O} / \mathrm{F}$ ratio of 0.0 . At the $40-w t \%$ He level, the $50-w t \%$ B engine $I_{s p}$ is 522.3 seconds. This large disparity in the $I_{s p}$ values leads to large differences in vehicle GLOW, and implies that the higher $\mathrm{O} / \mathrm{F}$ ratios will be more important in reducing vehicle GLOW, especially if higher wt $\%$ of helium are required.

Carbon: The engine $I_{\mathrm{sp}}$ data for the carbon cases is depicted in Figures 4 and 5. For the 24-wt\% $\mathrm{C}$ engine, the maximum $\mathrm{I}_{\mathrm{sp}}$ value is 512.5 seconds at an $\mathrm{O} / \mathrm{F}$ ratio of $0.0(00-\mathrm{wt} \%$ helium). Using a $40-\mathrm{wt} \%$ helium addition with $24-\mathrm{wt} \% \quad \mathrm{C}$, the $I_{\mathrm{sp}}$ drops to 402.8 seconds. With the $50-w t \% \mathrm{C}$ cases (with $00-w t \%$ helium), the maximum $I_{s p}$ is 696.4 seconds. For the $50-w 1 \% \mathrm{C}$ with the added $40-\mathrm{wt} \%$ helium, the $\mathrm{I}_{\mathrm{sp}}$ drops to 570.7 seconds.

As with the boron cases, the atomic carbon engine showed lower performance at the lower $\mathrm{O} / \mathrm{F}$ ratios when operating at the high helium wt $\%$ values. The monopropellant cases showed the greatest sensitivity to helium addition, and this low $\mathbf{I}_{\mathrm{sp}}$ will dramatically increase the vehicle GLOW. Operating at the higher $\mathrm{O} / \mathrm{F}$ ratios will assist in reducing the vehicle GLOW.

Hydrogen: The atomic hydrogen engine $I_{s p}$ is depicted in Figures 6,7 , and 8 . The engine performance was predicted for $10-, 15-$, and $50-w t \%$ $H$. For the $10-w t \%$ cases, the engine $I_{s p}$ showed great sensitivity to $\mathrm{He}$ addition at the low $\mathrm{O} / \mathrm{F}$ cases. For this $10-w t \% H$ engine, the maximum $I_{s p}$ value is 611.8 seconds at an $\mathrm{O} / \mathrm{F}$ ratio of $0.5(00-w t \% \mathrm{He})$. At the $15-w 1 \% \mathrm{H}$ atom loading, the maximal engine performance is 750 seconds $(O / F=0.0)$. With the $40-w t \%$ helium addition, the $I_{\mathrm{sp}}$ drops to 588 seconds. Using the $50-w t \% \mathrm{H}(00-w t \% \mathrm{He})$, the engine $I_{s p}$ is highest at an $O / F$ of $0.0: 1282$ seconds. By adding $40-w t \% H e$, the $I_{\mathrm{sp}}$ was reduced to 1046 seconds.

\section{Vehicle Design Assumptions}

In sizing the vehicles, the basic assumptions from Ref. 1 were used. All of the rocket vehicles are 2 stage designs. The payload to orbit for all the vehicles was $96,000 \mathrm{~kg}$. In all cases, liquid $\mathrm{O}_{2}$ is the oxidizer. Oxygen was selected, as it is a traditional oxidizer, and matched that of the NLS baseline vehicle. The range of $\mathrm{O} / \mathrm{F}$ ratios for the atomic rockets was 0.0 to 5.0. An estimate of the tank mass was made using a 6.1 meter diameter tank, for most 
cases. The lowest $\mathrm{O} / \mathrm{F}$ cases, 0.5 and 1.0, typically required a smaller 4.1 meter diameter tank to accommodate the smaller amount of $\mathrm{O}_{2}$.

Mass Scaling Equations

The mass scaling equations have the general formula of (Ref. 1):

$M_{\text {dry }}(k g)=A+B M_{p}$

Summaries of the mass scaling parameters are presented in Tables I through IV. Each table presents a different $\mathrm{O} / \mathrm{F}$ ratio for the propulsion system dry mass. The comparison of the monopropellant $(\mathrm{O} / \mathrm{F}=0.0$, in Table $\mathrm{I})$ and the bipropellant scaling equations (in Tables II, III, and IV) showed that the B factor is substantially reduced when designing the bipropellant propulsion systems. This reduction is the result of the higher density of the $\mathrm{O}_{2}$. As the $\mathrm{O} / \mathrm{F}$ ratio increases, the higher density oxygen is replacing some of the lower density atomic fuel. Using the higher density oxygen also reduces the engine $I_{\mathrm{sp}}$, but in the overall design, the GLOW of the vehicle can be reduced over the monopropellant case. Higher propellant density results in lower vehicle dry mass, and volume over the vehicle using the lower density atomic fuel.

The monopropellant vehicle GLOW values were taken from Ref. 1. These cases were compared with the bipropellant cases, and in many instances, the bipropellant vehicles had substantially lower GLOW values. This effect was especially noted in the low atom wt\% cases for $\mathrm{B}, \mathrm{C}$ and $\mathrm{H}$.

\section{RESULTS}

The results presented here are the GLOW of the atomic vehicles, and their dry masses. The GLOW is very important, as it shows the potential for increasing the payload capacity of rocket vehicles. The dry mass is also a historically important parameter in estimating the cost of propulsion systems (Ref. 30), and these data are also presented. Vehicle costs were not estimated in this paper, but the information is provided to assist future cost estimators in their analyses.

\section{Gross Lift Off Weight}

Boron: Figure 9 compares the GLOW of a 22-wt\% B rocket for both $00-w t \%$ He and $40-w t \%$ for the $\mathrm{O} / \mathrm{F}$ range of 0.0 to 5.0 . The $22-\mathrm{wt} \% \mathrm{~B}$ vehicle with $00-w 1 \%$ He has a minimum GLOW value at an $\mathrm{O} / \mathrm{F}$ ratio of 2.0 , at $2,260,000 \mathrm{~kg}$, but the minimum exists broadly between the 1.0 and $3.0 \mathrm{O} / \mathrm{F}$ ratios. The monopropellant case $(\mathrm{O} / \mathrm{F}=0.0)$ was a tremendously high number, over $9,190,000 \mathrm{~kg}$. For the $22-w t \%$ cases, none of these vehicles had a lower GLOW than the baseline $\mathrm{O}_{2} / \mathrm{H}_{2}$ vehicle.

With the 22-wt\% B cases with 40-wt\% He, the minimum GLOW is at $\mathrm{O} / \mathrm{F}$ ratio of 2.0 , at $2,768,000 \mathrm{~kg}$. The monopropellant case has a GLOW of $82,219,000 \mathrm{~kg}$, which is quite impractical. Bipropellant operation does indeed have a powerful effect on reducing the GLOW for these lower 22-wt\% cases. As with the 22 -wt $\%$ cases with 00 -wt $\% \mathrm{He}$, none of these vehicles had a lower GLOW than the baseline $\mathrm{O}_{2} / \mathrm{H}_{2}$ vehicle.

Using 50-wt $\%$ B with $00-w t \%$ He, the vehicle GLOW is significantly lower than that for the $\mathrm{O}_{2} / \mathrm{H}_{2}$ vehicle: only $1,145,700 \mathrm{~kg}$. These results are shown in Figure 10. The atomic B rocket has a lower GLOW than the $\mathrm{O}_{2} / \mathrm{H}_{2}$ vehicle until it reaches an $\mathrm{O} / \mathrm{F}$ ratio of 3.0. Therefore the best operating point for the atomic $B$ rocket is between and $O / F$ of 0.0 and 1.0. Atomic $B$ vehicle operating at $\mathrm{O} / \mathrm{F}$ ratios less than 1.0 will have a significantly lower GLOW than an $\mathrm{O}_{2} / \mathrm{H}_{2}$ vehicle, and thus show a vehicle benefit.

When operating at $50-\mathrm{wt} \% \mathrm{~B}$ with $40-\mathrm{wt} \% \mathrm{He}$, the vehicle GLOW shows a minimum between and $\mathrm{O} / \mathrm{F}$ ratio of 0.5 to 1.0 . Both of these $\mathrm{O} / \mathrm{F}$ ratios deliver atomic $B$ vehicle GLOW values that are below the baseline $\mathrm{O}_{2} / \mathrm{H}_{2}$ vehicle's GLOW.

Carbon: Atomic C rocket GLOW with 24-wt\% $\mathrm{C}$ and $50-\mathrm{wt} \% \mathrm{C}$ is illustrated in Figures 11 and 12. An atomic $C$ rocket with $24-w t \% C$ and $00-\mathrm{wt} \%$ He has a minimum GLOW at the O/F of 3.0: $2,245,000 \mathrm{~kg}$. With the $40-\mathrm{wt} \% \mathrm{He}$, the same B loading delivers a minimum GLOW of $2,815,700 \mathrm{~kg}$. Both of these cases are greater in mass that the GLOW of the baseline vehicle.

At the $50-\mathrm{wt} \% \mathrm{C}$ case $(00-\mathrm{wt} \% \mathrm{He})$, the vehicle GLOW is a minimum at an O/F of $0.0: 975,200 \mathrm{~kg}$. In all of the higher $\mathrm{O} / \mathrm{F}$ cases, the GLOW was higher than the monopropellant case. At the $50-\mathrm{wt} \% \mathrm{C}$ case with $40-w t \% \mathrm{He}$, the minimum GLOW occurred at an $\mathrm{O} / \mathrm{F}$ of $0.0: 1,735,200 \mathrm{~kg}$. As with the boron cases, the $50-\mathrm{wt} \%$ vehicle may be able to operate at a higher $\mathrm{O} / \mathrm{F}$ ratio, and still show a significant reduction in GLOW over the baseline vehicle.

Hydrogen: The atomic hydrogen GLOW values are depicted in Figure 13, 14, and 15. For the 10 -wt $\% \mathrm{H}$ cases with $00-\mathrm{He}$ wt $\%$, the GLOW values 
show a minimum in the $\mathrm{O} / \mathrm{F}$ range of 1.0 to 2.0 . Operating the atomic hydrogen vehicle at the $\mathrm{O} / \mathrm{F}$ of 1.0 or 2.0 also reduced the GLOW below that of the baseline $\mathrm{O}_{2} / \mathrm{H}_{2}$ vehicle: $1,834,000 \quad \mathrm{~kg}$ versus $1,891,500$ for the $\mathrm{O}_{2} / \mathrm{H}_{2}$ vehicle. For the 10 -wt $\%$ cases with $40-w t \% \mathrm{He}$, the higher $\mathrm{O} / \mathrm{F}$ ratios can significantly reduce the GLOW. The minimum GLOW occurs at in the range of $\mathrm{O} / \mathrm{F}$ ratio of 2 or 3 . The minimum GLOW at an $\mathrm{O} / \mathrm{F}$ of 3.0 is $2,330,000 \mathrm{~kg}$. Unfortunately, this GLOW is higher than the baseline $\mathrm{O}_{2} / \mathrm{H}_{2}$ vehicle. Thus the 10 -wt $\% \mathrm{H}$ vehicle seem to have only a very small benefit in reducing vehicle GLOW.

With the $15-w t \%$ cases with $00-w t \%$ He, the GLOW was not reduced by operating at higher $\mathrm{O} / \mathrm{F}$ ratios. The minimum GLOW occurred at an $\mathrm{O} / \mathrm{F}$ of 0.0 and the GLOW was $1,057,600 \mathrm{~kg}$. Operating at higher $\mathrm{O} / \mathrm{F}$ ratios only increased the GLOW. Though the GLOW was increased, there is the possibility of reducing the overall vehicle operating costs by using the higher $\mathrm{O} / \mathrm{F}$ ratios. At the higher $\mathrm{O} / \mathrm{F}$, the amount of atomic hydrogen needed is significantly reduced, and the size of the facility or production rate for the atomic hydrogen can be reduced.

When the He addition is $40-\mathrm{wt} \%$ with the $15-\mathrm{wt} \% \mathrm{H}$ cases, the GLOW shows a minimum value in the $O / F$ range of 1.0 to 2.0 . However, there is only a small reduction in GLOW over the baseline $\mathrm{O}_{2} / \mathrm{H}_{2}$ vehicle. At an O/F of 1.0, the atomic $H$ GLOW is $1,842,000$ versus $1,891,500 \mathrm{~kg}$ for the baseline vehicle. If the $\mathrm{He}$ addition could be reduced to $10-$ or $20-\mathrm{wt} \%$, there is still the potential for significantly reducing the vehicle GLOW below the baseline case.

At the $50-\mathrm{wt} \% \mathrm{H}$ cases with $00-\mathrm{wt} \% \mathrm{He}$, the vehicle GLOW is always greatly reduced over the $\mathrm{O}_{2} / \mathrm{H}_{2}$ baseline case. The monopropellant case $(\mathrm{O} / \mathrm{F}=0.0)$ reduced the GLOW to $411,000 \mathrm{~kg}$, which is less than $22 \%$ over the $\mathrm{O}_{2} / \mathrm{H}_{2}$ vehicle GLOW. With the $50-w 1 \%$ H cases, the GLOW was increased by increasing the $\mathrm{O} / \mathrm{F}$ ratio. As noted earlier, operating the vehicle at a higher $\mathrm{O} / \mathrm{F}$ ratio can reduce the facility size and production rate for atomic fuels. Even if the GLOW is increased over the minimum value, operating at a higher $\mathrm{O} / \mathrm{F}$ ratio may significantly reduce the overall cost of the atomic vehicle.

Using the 50-wt\% $\mathrm{H}$ case with $40-\mathrm{wt} \% \mathrm{He}$, the GLOW is still a small fraction of the $\mathrm{O}_{2} / \mathrm{H}_{2}$ baseline GLOW: only $518,000 \mathrm{~kg}$. As the $\mathrm{O} / \mathrm{F}$ ratio increased, the GLOW also increased. Even at the $\mathrm{O} / \mathrm{F}$ of 2.0 , the GLOW was still less than $50 \%$ of the baseline
GLOW, with the atomic $\mathrm{H}$ vehicle weighing in at a mere $930,000 \mathrm{~kg}$.

\section{Vehicle Dry Masses}

The atomic rocket dry masses were computed as a part of the GLOW calculations and are presented here in Figures 16 through 22. In past analyses, the space vehicle dry mass is often used as an important parameter in space mission cost estimating (Ref. 30). The dry masses are therefore presented to assist in future cost estimates for these vehicles.

Boron: The dry masses of the atomic $B$ vehicles are presented in Figures 16 and 17. For the $22-w t \%$ cases, the minimum dry masses occur at an $\mathrm{O} / \mathrm{F}$ ratio of 2.0 , and the mass is $371,500 \mathrm{~kg}$. For comparison, the baseline $\mathrm{O}_{2} / \mathrm{H}_{2}$ vehicle dry mass was $197,800 \mathrm{~kg}$. At the $50-\mathrm{wt} \% \mathrm{~B}$ case, the dry mass is almost as low as the baseline case: $210,000 \mathrm{~kg}$ at an $\mathrm{O} / \mathrm{F}$ of 0.5 .

Carbon: Figures 18 and 19 illustrate the atomic $\mathrm{C}$ dry mass optimizations. With atomic $\mathrm{C}$ (24-wt $\% \mathrm{C}, 00-\mathrm{wt} \% \mathrm{He}$ ), the dry mass minimum occurs at the $\mathrm{O} / \mathrm{F}$ ratio of 3.0 and the mass was $383,000 \mathrm{~kg}$. Using $50-\mathrm{wt} \% \mathrm{C}(00-\mathrm{wt} \% \mathrm{He})$, the minimum dry mass was $185,300 \mathrm{~kg}(\mathrm{O} / \mathrm{F}=0.0)$. This case is where the atomic rocket has a lower dry mass that the baseline mass of $197,000 \mathrm{~kg}$.

Hydrogen: Dry masses for atomic $\mathrm{H}$ vehicles are depicted in Figures 20, 21, and 22 for 10-, 15and $50-w t \%$ atom loadings of $H$. In the three $H$ cases, the only design that reduced the dry mass below the baseline case was the $50-w t \% \mathrm{H}$ vehicle: $91,600 \mathrm{~kg}$ $(\mathrm{O} / \mathrm{F}=0.0)$. Even the $40-\mathrm{wt} \%$ He case with 50 -wt $\%$ $\mathrm{H}$ was able to reduce the dry mass significantly below the baseline mass: $112,000 \mathrm{~kg}$. Atomic hydrogen appears to be the most capable propellant for reducing both GLOW and dry mass.

\section{OBSERVATIONS}

Atomic rocket designs have much sensitivity to engine $I_{s p}$, and dry mass, and $O / F$ ratio. Engine $I_{s p}$ was shown to be an important aspect of reducing vehicle GLOW for atomic $B, C$, and $H$ rockets (50-wt \% cases). For these $50-w t \%$ cases, the best atomic $\mathrm{B}, \mathrm{C}$, and $\mathrm{H}$ GLOW operating point seems to be the monopropellant case $(\mathrm{O} / \mathrm{F}=0.0)$. However, operating at an O/F of 1.0 or 2.0 still provides a low GLOW, and significantly reduces the total production of atomic propellant for each vehicle. Atomic propellant vehicles using bipropellant combinations 
can substantially reduce the mass of atomic fuel needed. This reduction can reduce the overall production facilities for the fuel, and reduce the cost of the advanced technology vehicle and propellant.

With the lower wt\% atomic fuel cases, though the Isp values were relatively low for the higher $\mathrm{O} / \mathrm{F}$ cases, the overall bipropellant vehicle GLOW and dry mass were greatly reduced over the $B, C$, and $H$ monopropellant vehicle cases. A monopropellant atomic B vehicle had a GLOW of over $82,000,000 \mathrm{~kg}$ and the optimal design at an $\mathrm{O} / \mathrm{F}$ of 2.0 reduced the GLOW to $2,226,000 \mathrm{~kg}$, a phenomenal mass reduction.

In the GLOW analyses presented here, the effects of helium addition were also small in some cases for lower atom wt\% values, especially, at the higher $\mathrm{O} / \mathrm{F}$ ratios. In the boron and carbon cases, the vehicle GLOW is surprisingly insensitive to the He addition near the minimum GLOW values. The GLOW of the atomic B vehicle (22-wt \% B) in Figure 9 and atomic $C$ vehicle (24-wt\% C) in Figure 11 show that there was little difference between the GLOW values for the $00-w t \%$ He and the $40-w t \%$ He cases. This result was unexpected and can be a powerful tool in creating a practical atomic fueled vehicle.

Once the GLOW is computed and compared to the baseline $\mathrm{O}_{2} / \mathrm{H}_{2}$ vehicle, the mass difference between the baseline and the new atomic rocket can be used to estimate the potential payload increase. These analyses were based on the assumption that the atomic rocket GLOW can be allowed to equal the baseline vehicle GLOW. With atomic boron rockets, the payload increases can be $70 \%$, whereas if atomic hydrogen were proven feasible in some far future, the payload increase might be $360 \%$.

The GLOW and dry mass data can be used to estimate the cost of future vehicles and their atomic propellant production facilities. The lower the propellants mass, the lower the overall investment for the specially manufactured atomic propellants.

\section{CONCLUSIONS}

Using a bipropellant oxygen/ atomic fueled vehicle very significantly reduced the GLOW of atomic rockets. All of the cases using less than 50-wt\% atomic fuel loading, the vehicle GLOW showed an optimum or minimum GLOW between an $\mathrm{O} / \mathrm{F}$ ratio of 1.0 and 3.0. This minimization of the GLOW is important for the lower wt $\%$ atomic loading cases, as they may be the first implementations of these very advanced rocket fuels. Monopropellant operation $(\mathrm{O} / \mathrm{F}=0.0)$ provided the lowest GLOW values for the vehicles using 50-wt \% atomic fuel: B, C, or $\mathrm{H}$.

In many cases, operating the atomic propellant vehicle at $O / F$ ratios of $1-3$ is very effective in reducing the atomic fuel needed and, ultimately, the fuel production costs. Using the $22-w t \%$ B cases, the overall mass of fuel was reduced by nearly a factor of 2 percent with an $\mathrm{O} / \mathrm{F}$ of 1.0 . The best $\mathrm{O} / \mathrm{F}$ ratio appears to be 2.0 for minimum GLOW. The overall system design, which balanced the GLOW reduction, dry mass, and fuel production needs, implies an $\mathrm{O} / \mathrm{F}$ ratio between 1.0 to 3.0 was best.

A technology assessment of atomic propellants has shown that atomic boron and carbon rocket analyses are considered to be much more near term options than the atomic hydrogen rockets (Ref. 4-11, and 31). The technology for storing atomic boron and carbon has shown significant progress, while atomic hydrogen is not able to be stored at the high densities needed for effective propulsion. Future near term work should concentrate on atomic boron and atomic carbon propellants.

In the boron and carbon rocket cases, operating the vehicle at an O/F ratio of 2 to 4 showed that the rocket $I_{\mathrm{sp}}$ was little influenced by the addition of helium. The GLOW of the vehicle using 40-wt\% $\mathrm{He}$ was not greatly increased over the $00-w t \%$ cases. If there is a small effect of the helium addition on the engine $l_{\mathrm{sp}}$, this fact can be used to ease the design challenges of the feed system. With a larger helium wt $\%$, there is a better chance to make the solid particle feed system successful.

\section{CONCLUDING REMARKS}

Atomic fuels have the potential for revolutionizing aerospace vehicles. Airbreathing propulsion systems may use them to accelerate the combustion process in scramjet engines (Ref. 32). Rocket engine $I_{\text {sp }}$ can be significantly increased, but the density of the fuel and the vehicle must be selected to make the vehicle as effective as possible. Selection of the "best" O/F ratios for the atomic rocket vehicle can reduce the GLOW very significantly, and make the vehicles of a practical size and mass. Cost estimates of future vehicles must include the very expensive atomic propellant facilities. The operation of atomic chemically-propelled rockets may be driven by operating far from the theoretical maximum $I_{s p}$ 
values, and be more controlled by the forces of economics. As our understanding of the basic physics of atomic propellants increases, the perceived costs of creating "impossible" atomic propellants will drop, and a new era of engineering, physics, and exploration will begin.

\section{$\underline{\text { REFERENCES }}$}

1) Palaszewski, B., "Launch Vehicle Performance with Solid Particle Feed Systems for Atomic Propellants," AIAA 98-3736, NASA TM 1998208498, presented at the $34^{\text {th }}$ AIAA/ASME/SAE Joint Propulsion Conference, Cleveland, $\mathrm{OH}$, July 1998.

2) Palaszewski, B., "Metallized Propellants for the Human Exploration of Mars," NASA Lewis Research Center, NASA TP-3062, presented at the Case For Mars IV Conference, Boulder, CO, June 4-8 1990. Also in the AIAA Journal of Propulsion and Power, Vol. 8, No. 6, Nov.-Dec. 1992, pp. 1192-1199.

3) Palaszewski, B., "Atomic Hydrogen Propellants: Historical Perspectives and Future Possibilities," NASA-Lewis Research Center, AIAA 93-0244, presented at the $31^{\text {st }}$ AIAA Aerospace Science Meeting, Reno, NV, January 11-14, 1993.

4) Carrick, P., and Tam, S., Editors, "Proceedings of the High Energy Density Materials (HEDM) Contractors' Conference held 4-7 June 1995 in Woods Hole, MA," USAF Phillips Laboratory, Report Number PL-TR-95-3039, January 1996.

5) Thompson, T. L., and Rodgers, S. L., Editors, "Proceedings of the High Energy Density Materials (HEDM) Contractors' Conference held 5-7 June 1994 in Crystal Bay, NV," USAF Phillips Laboratory, Report Number PL-TR-943036, December 1994.

6) Thompson, T. L., Editor, "Proceedings of the High Energy Density Materials (HEDM) Contractors' Conference held 6-8 June 1993 in Woods Hole, MA," USAF Phillips Laboratory, Report Number PL-TR-93-3041, November 1993.

7) Berman, M., Editor, "Proceedings of the High Energy Density Materials (HEDM) Contractors' Conference held 5-7 June 1992 in Crystal Bay, NV," Air Force Office of Scientific Research, November 1992.
8) Thompson, T. L., Editor, "Proceedings of the High Energy Density Materials (HEDM) Contractors" Conference held 24-27 February 1991 in Albuquerque, NM," USAF Phillips Laboratory, Report Number PL-TR-91-3003. October 1991.

9) Davis, L., and Wodarczyk. F., Editors, "Proceedings of the High Energy Density Materials (HEDM) Contractors' Conference, 25-28 February 1990, Long Beach, CA," Air Force Office of Scientific Research, May 1990.

10) Wiley, T.G, and van Opinjnen, R.A., Editors, "Proceedings of the High Energy Density Materials (HEDM) Contractors' Conference held 12-15 March 1989 in New Orleans, LA," USAF Astronautics Laboratory (AFSC), Report Number AL-CP-89-002, July 1989.

11) Davis, L.. and Wodarczyk, F., Editors, "Proceedings of the High Energy Density Materials (HEDM) Contractors' Conference, 28 February- 2 March 1988, Newport Beach, CA," Air Force Office of Scientific Research, May 27. 1988.

12) Palaszewski, B., "Atomic Hydrogen As A Launch Vehicle Propellant," NASA-Lewis Research Center, AIAA $90-0715$, presented at the $28^{\text {th }}$ AIAA Aerospace Science Meeting, Reno, NV, January 8-11, 1990.

13) Carrick, P., "Specific Impulse Calculations of High Energy Density Solid Cryogenic Rocket Propellants, 1: Atoms in Solid Hydrogen," USAF Phillips Laboratory Report PL TR -93-3014, April 1993.

14) Collins, G., et al., "Triggered Energy Releases in Solid Hydrogen Hosts Containing Unpaired Atoms," Physical Review Letters, Volume 65, No. 4, pp. 444-447, July 23, 1990.

15) Lee, Timothy J., and Rice, Julia E., "Theoretical Characterization Of Tetrahedral N4," Journal of Chemical Physics, Vol. 94, Jan. 15, 1991, pp. 1215-1221.

16) Segal, C., Friedauer, M.J., Udaykumar, H.S., Shyy, W., and Marchand, A.P., "Ignition Characteristics of A New High-Energy Density Fuel In High-Speed Flows," Journal of Propulsion and Pow'er, Vol. 13, No. 2, Mar.-Apr. 1997, pp. 246-249. 
17) Seidl, Edward T., Schaefer, Henry F., III, "Theoretical Studies Of Oxygen Rings Cyclotetraoxygen, (O4)," Journal of Chemical Physics, Vol. 88, June 1, 1988, pp. 7043-7049.

18) Gordon, E.B., et al., "Metastable ImpurityHelium Solid Phase: Experimental and Theoretical Evidence," Chemical Physics, Vol. 170, (1993), pp. 411-426.

19) Scharf, D., et al., "Nature of Lithium Trapping Sites in the Quantum Solids Para-Hydrogen and Ortho-Deuterium," Journal of Chemical Physics, Vol. 99, No. 11, December 1993, pp. 9013-9020.

20) Eaton, P., Or, Y., and Branca, S., "Pentaprismane," Joumal of the American Chemical Societv, Vol. 103 (1981), pp. 21342136.

21) Matsunaga, N. and Gordon, S., "Stabilities and Energetics of Inorganic Benzene Isomers: Prismanes," Journal of the American Chemical Society, Vol. 166, (1994), pp. 11407-11419.

22) Lauderdale, W., Stanton, J., Bartlett, R., "Stability and Energetics of Metastable Molecules: Tetraazatetrahedrane (N4), Hexaazabenzene (N6), and Octaazacubane (N8)," Journal of Physical Chemistry, Vol. 96, (1992), pp. 1173-1178.

23) Watts. John D. Bartlett, Rodney J., "CoupledCluster Calculations on the C2 Molecule and the $\mathrm{C} 2(+)$ and C2(-) Molecular Ions," Journal of Chemical Physics, Vol. 96, April 15, 1992, pp. 6073-6084.

24) Fajardo, Mario E., "Limitations On Stored Energy Densities In Systems Of Separated Ionic Species, " Journal of Propulsion and Power, Vol. 8, Jan.-Feb. 1992, p. 30-36.
25) Fajardo, M., Carrick, P., and Kenney, J. III, "Matrix Isolation Spectroscopy Of Metal Atoms Generated By Laser Ablation. I - The Li/Ar, $\mathrm{Li} / \mathrm{Kr}$, And Li/Xe Systems," Joumal of Chemical Physics, Vol. 94, May 1, 1991, pp. 5812 - 5825.

26) Brazier, C. and Carrick, P. "Observation of Several New Electronic Transitions Of The B2 Molecule," Journal Of Chemical Physics, Vol. 96, No. 12, June 15, 1992, pp. 8684-8690.

27) Palaszewski, B., Ianovski, L., and Carrick, P., "Propellant Technologies: A Persuasive Wave of Future Propulsion Benefits," presented at the $3^{\text {rd }}$ Intemational Symposium on Space Propulsion, Beijing, China, August 11-13, 1997.

28) Palaszewski, B., Ianovski, L., and Carrick, P., "Propellant Technologies: Far Reaching Benefits for Aeronautical and Space Vehicle Propulsion," in the Special Edition of the AIAA Journal of Propulsion and Power, September/October 1998, pp. 641-648.

29) McBride, B. and Gordon, Sanford, "Computer Program for Calculation of Complex Chemical Equilibrium Compositions and Applications. Part 1: Analysis," NASA RP-1311, October 1994.

30) Koelle, H., H., (editor), Handbook of Astronautical Engineering, McGraw Hill Book Co., New York, 1961.

31) Mario Fajardo, USAF Research Laboratory, Edwards, CA, June 1999, Personal Communications.

32) Bushnell, D., "Far Term Visions: The Frontiers of the Responsibly Imaginable," Transportation Beyond 2000: Technologies Needed for Engineering Design, pp. 261-295, Feb. 1, 1996. 
Table I

Dry Mass Scaling Parameters for Atomic

Rockets: $\mathrm{O} / \mathrm{F}=0.0$

\section{Atomic Boron}

$\begin{array}{cccc}\text { Wi\% B } & \text { Wi\% He } & \text { A } & \text { B } \\ 22 & 00 & 11.934 .32 & 0.29681 \\ 22 & 40 & 11,934.32 & 0.28302 \\ & & & \\ 50 & 00 & 11,934.32 & 0.24228 \\ 50 & 40 & 11.934 .32 & 0.25030\end{array}$

\section{Atomic Carbon}

$\begin{array}{cccc}\text { Wt } \% \text { C } & \text { Wi\% He } & \text { A } & \text { B } \\ & & & \\ 24 & 00 & 11,934.32 & 0.29340 \\ 24 & 40 & 11.934 .32 & 0.28097 \\ & & & \\ 50 & 00 & 11.934 .32 & 0.24328 \\ 50 & 40 & 11.934 .32 & 0.25089\end{array}$

\section{Atomic Hydrogen}

$\mathrm{Wt}_{\mathrm{t}} \mathrm{H} \quad \mathrm{W} \% \mathrm{He}$

A $\quad$ B

$\begin{array}{llll}10 & 00 & 11,934.32 & 0.33966 \\ 10 & 40 & 11,934.32 & 0.30867 \\ & & & \\ 15 & 00 & 11.934 .32 & 0.33966 \\ 15 & 40 & 11,934.32 & 0.30867 \\ & & & \\ 50 & 00 & 11.934 .32 & 0.33966 \\ 50 & 40 & 11.934 .32 & 0.30867\end{array}$

Table II

Dry Mass Scaling Parameters for Atomic Rockets: $\mathrm{O} / \mathrm{F}=1.0$

\section{Atomic Boron}

$\begin{array}{cccc}\text { Wi\% B } & \text { Wit He } & \text { A } & \text { B } \\ 22 & 00 & 11.516 .99 & 0.22327 \\ 22 & 40 & 11.898 .11 & 0.21638 \\ & & & \\ 50 & 00 & 11,516.99 & 0.19601 \\ 50 & 40 & 11.898 .11 & 0.20002\end{array}$

\section{Atomic Carbon}

$\begin{array}{cccc}\text { Wt } \% \mathrm{C} & \text { Wt } \% \mathrm{He} & \text { A } & \text { B } \\ & & & \\ 24 & 00 & 11.516 .99 & 0.22157 \\ 24 & 40 & 11,898.11 & 0.21535 \\ & & & \\ 50 & 00 & 11.516 .99 & 0.19650 \\ 50 & 40 & 11.898 .11 & 0.20031\end{array}$

\section{Atomic Hydrogen}

$\begin{array}{cccc}\text { Wi\% H } & \text { Wi } \% \text { He } & \text { A } & \text { B } \\ 10 & 00 & 11,898.11 & 0.24470 \\ 10 & 40 & 11,898.11 & 0.22923 \\ & & & \\ 15 & 00 & 11.898 .11 & 0.24470 \\ 15 & 40 & 11,898.11 & 0.22923 \\ 50 & 00 & 11,898.11 & 0.24470 \\ 50 & 40 & 11,898.11 & 0.22923\end{array}$


Table III

Dry Mass Scaling Parameters for Atomic

Rockets: $\mathrm{O} / \mathrm{F}=2.0$

Atomic Boron

$\begin{array}{cccc}\text { Wt } \% \mathrm{~B} & \text { Wt } \% \mathrm{He} & \mathrm{A} & \mathrm{B} \\ 22 & 00 & 11.516 .99 & 0.19876 \\ 22 & 40 & 11,516.99 & 0.19416 \\ & & & \\ 50 & 00 & 11.516 .99 & 0.18058 \\ 50 & 40 & 11.516 .99 & 0.18326\end{array}$

\section{Atomic Carbon}

Wis C Wt\% He

A

B

$\begin{array}{llll}24 & (0) & 11.516 .99 & 0.19762 \\ 24 & 40 & 11,516.99 & 0.19348\end{array}$

$\begin{array}{llll}50 & 00 & 11.516 .99 & 0.18091\end{array}$

$\begin{array}{llll}50 & 40 & 11,516.99 & 0.18345\end{array}$

\section{Atomic Hydrogen}

$\begin{array}{cccc}\text { Wt } \% \text { H } & \text { Wt } \% \mathrm{He} & \mathrm{A} & \mathrm{B} \\ 10 & 00 & 11,516.99 & 0.21304 \\ 10 & 40 & 11,516.99 & 0.20273 \\ & & & \\ 15 & 00 & 11.516 .99 & 0.21304 \\ 15 & 40 & 11,516.99 & 0.20273 \\ 50 & 00 & 11.516 .99 & 0.21304 \\ 50 & 40 & 11.516 .99 & 0.20273\end{array}$

Table IV

Dry Mass Scaling Parameters for Atomic Rockets: $\mathrm{O} / \mathrm{F}=3.0$

\section{Atomic Boron}

$\begin{array}{cccc}\text { Wic B } & \text { Wr\% He } & \text { A } & \text { B } \\ 22 & 00 & 11.516 .99 & 0.18650 \\ 22 & 40 & 11.516 .99 & 0.18306 \\ & & & \\ 50 & 00 & 11.516 .99 & 0.17287 \\ 50 & 40 & 11.516 .99 & 0.17488\end{array}$

\section{Atomic Carbon}

Wt\% Wi He A

$\begin{array}{llll}24 & (0) & 11.516 .99 & 0.18565 \\ 24 & 40 & 11,516.99 & 0.18254 \\ 50 & 00 & 11.516 .99 & 0.17312 \\ 50 & 40 & 11.516 .99 & 0.17502\end{array}$

\section{Atomic Hydrogen}

$\begin{array}{cccc}\text { Wt H } & \text { Wt\% He } & \text { A } & \text { B } \\ 10 & 00 & 11,516.99 & 0.19722 \\ 10 & 40 & 11,516.99 & 0.18948 \\ & & & \\ 15 & 00 & 11,516.99 & 0.19722 \\ 15 & 40 & 11,516.99 & 0.18948 \\ 50 & 00 & 11.516 .99 & 0.19722 \\ 50 & 40 & 11,516.99 & 0.18948\end{array}$




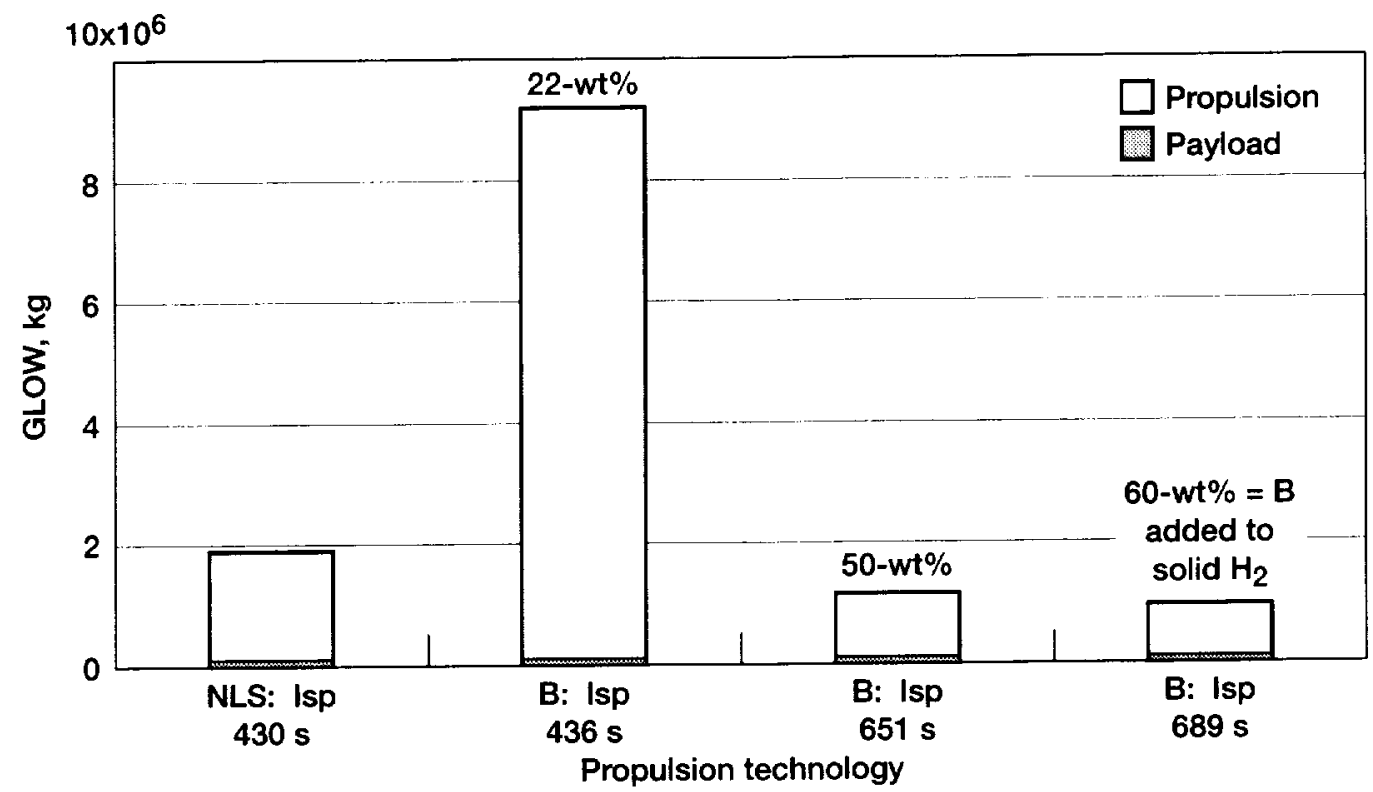

Figure 1.-Atomic boron GLOW for monopropellants: $22-, 50-$, and $60-w t \%$ B. No helium addition

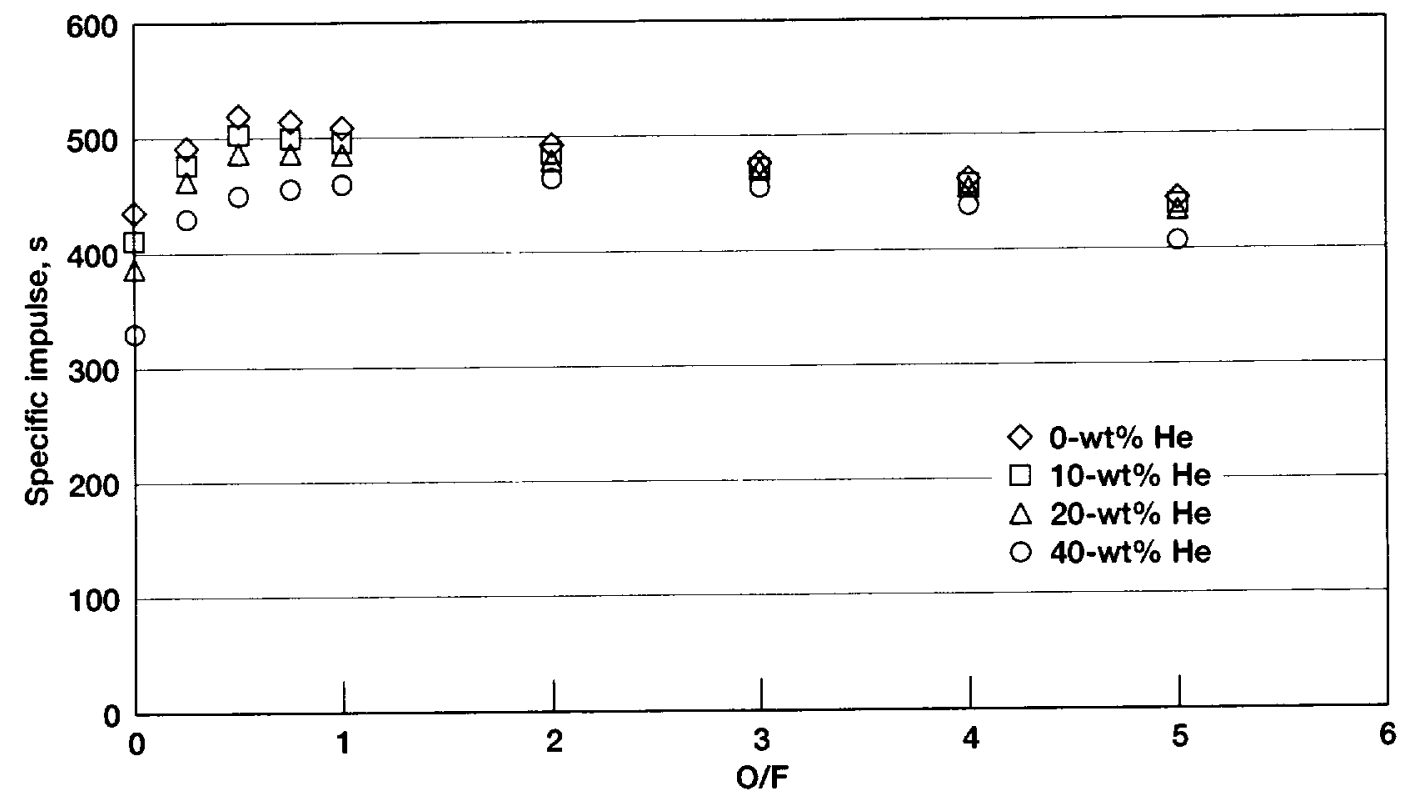

Figure 2.-Atomic boron engine performance: $22-w t \%$ B. 


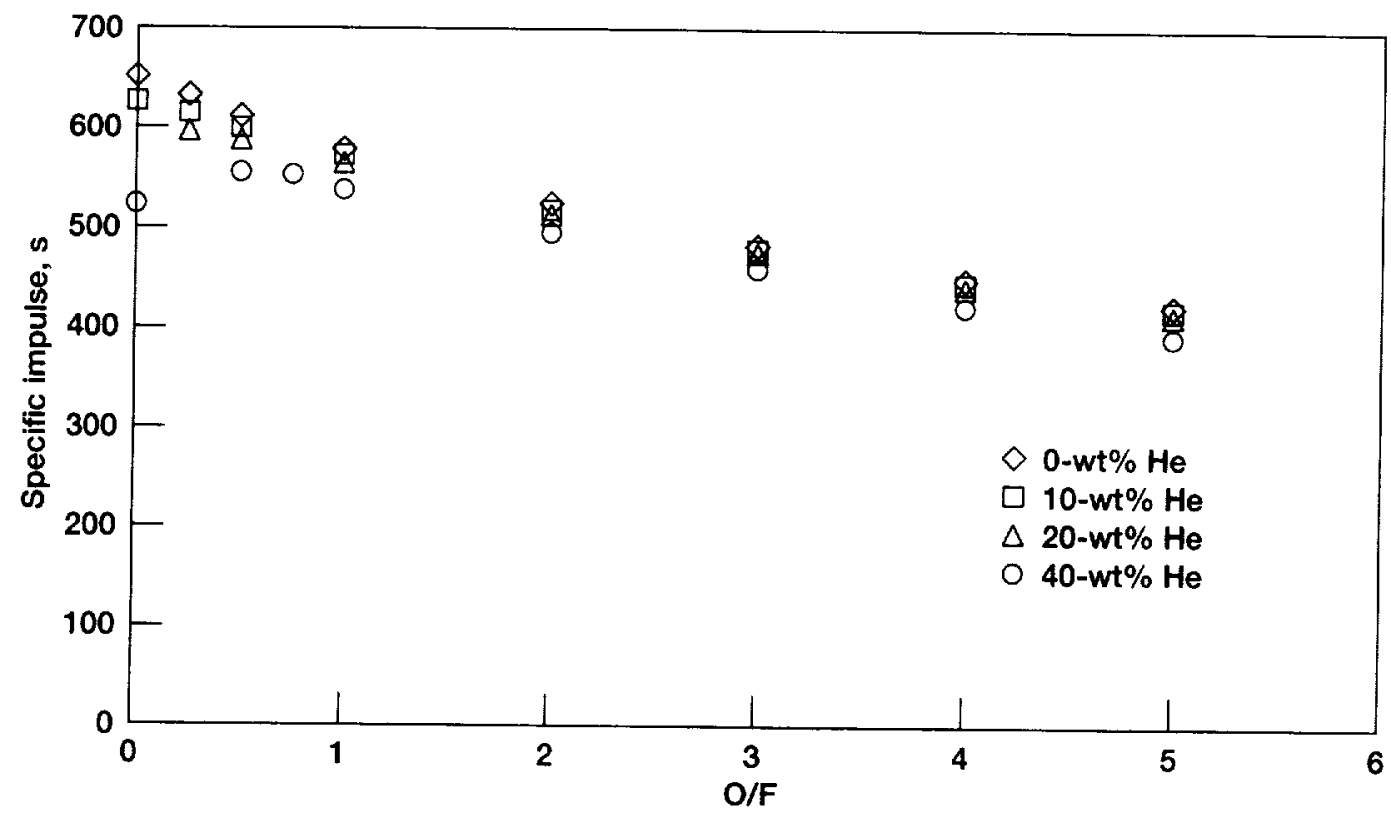

Figure 3.-Atomic boron engine performance: $50-w t \% B$.

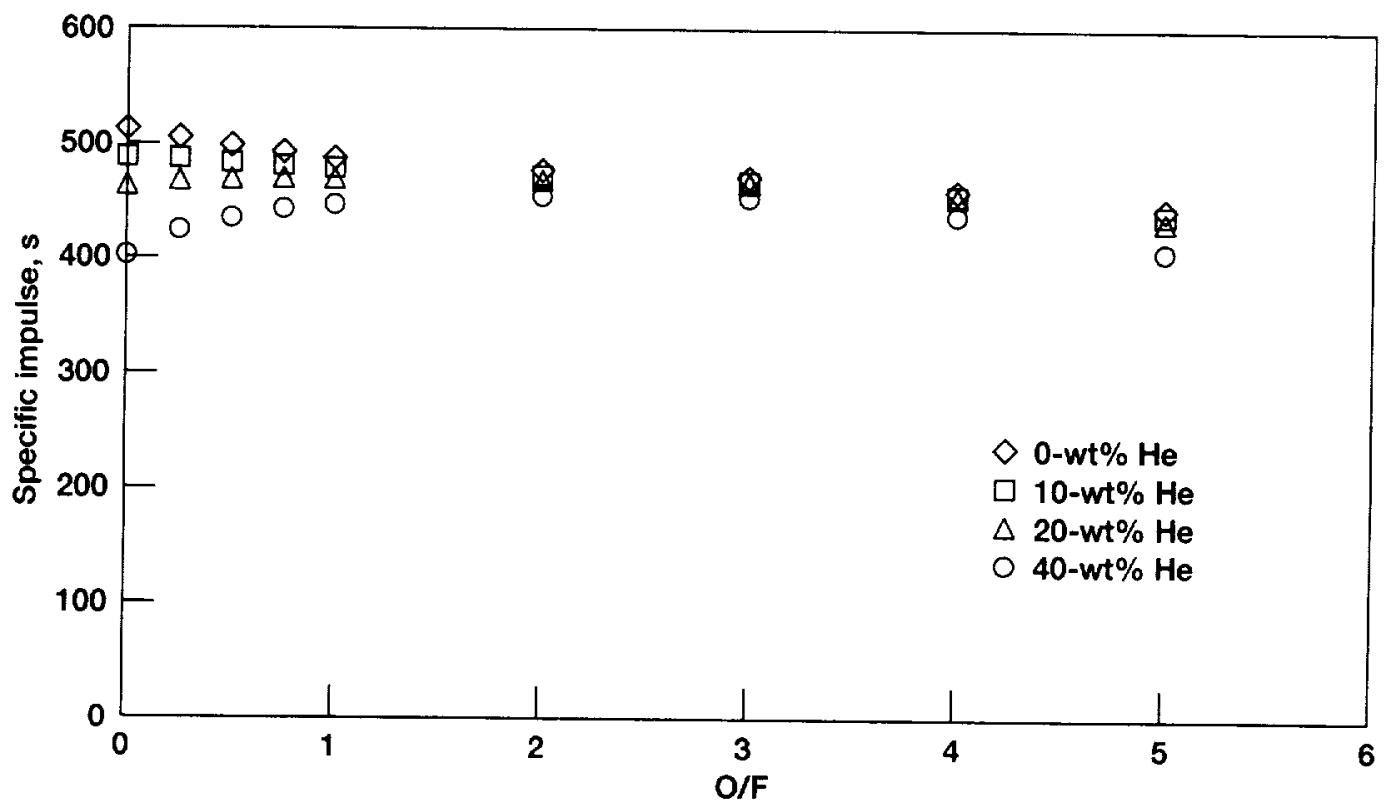

Figure 4.-Atomic carbon engine performance: $24-w t \% C$. 


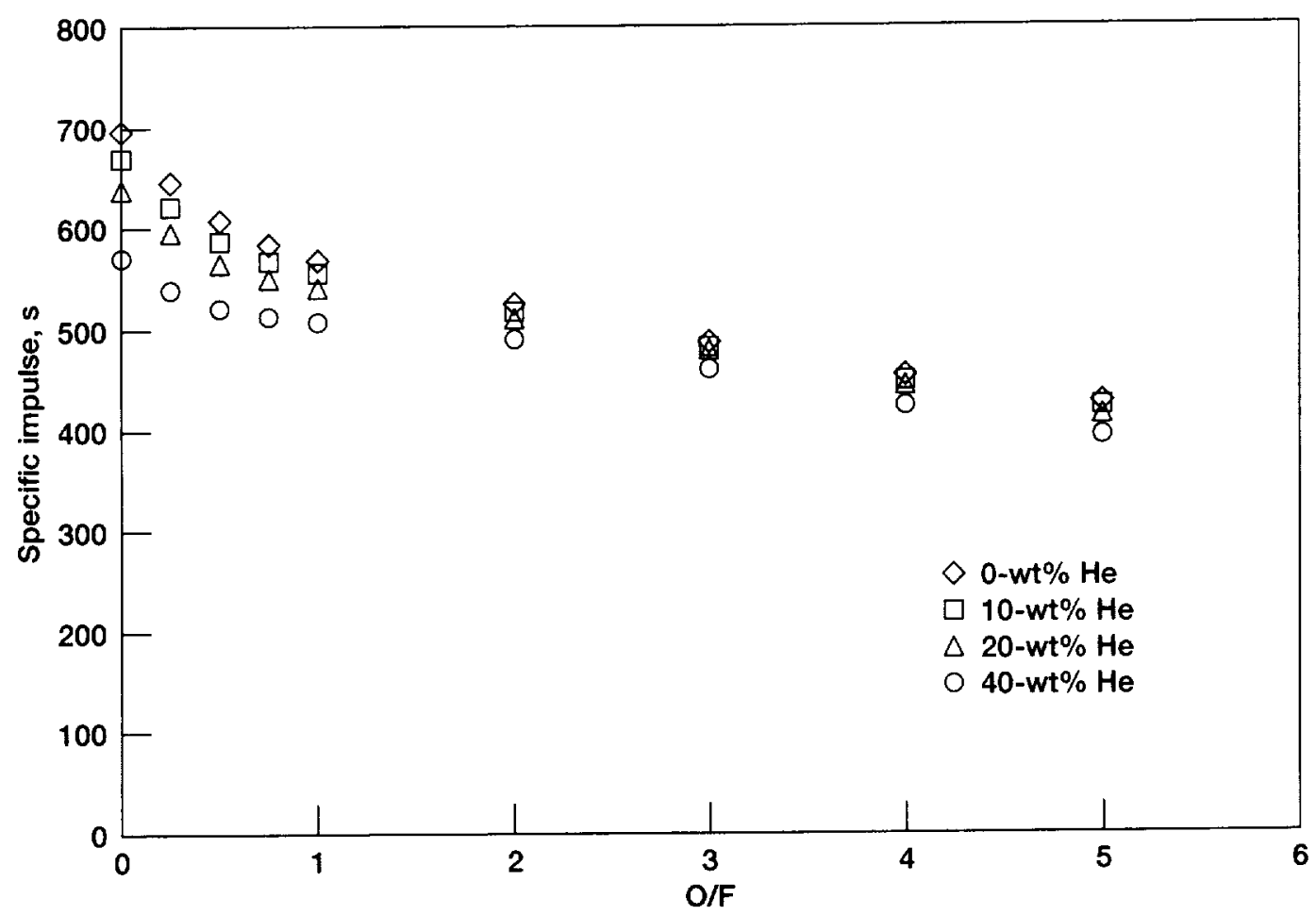

Figure 5.-Atomic carbon GLOW: $50-w t \%$ C.

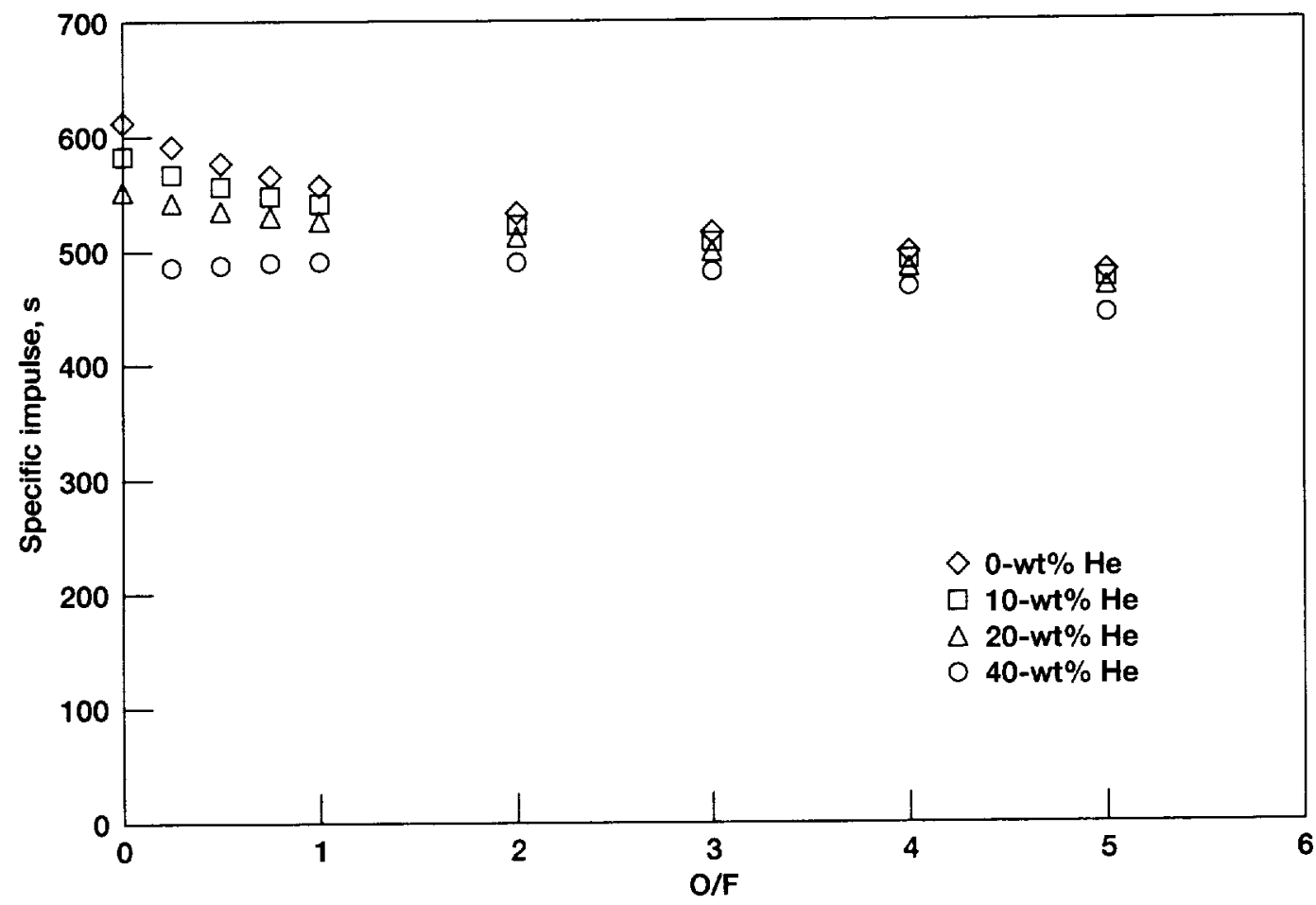

Figure 6.-Atomic hydrogen engine performance: $10-w t \% H$. 


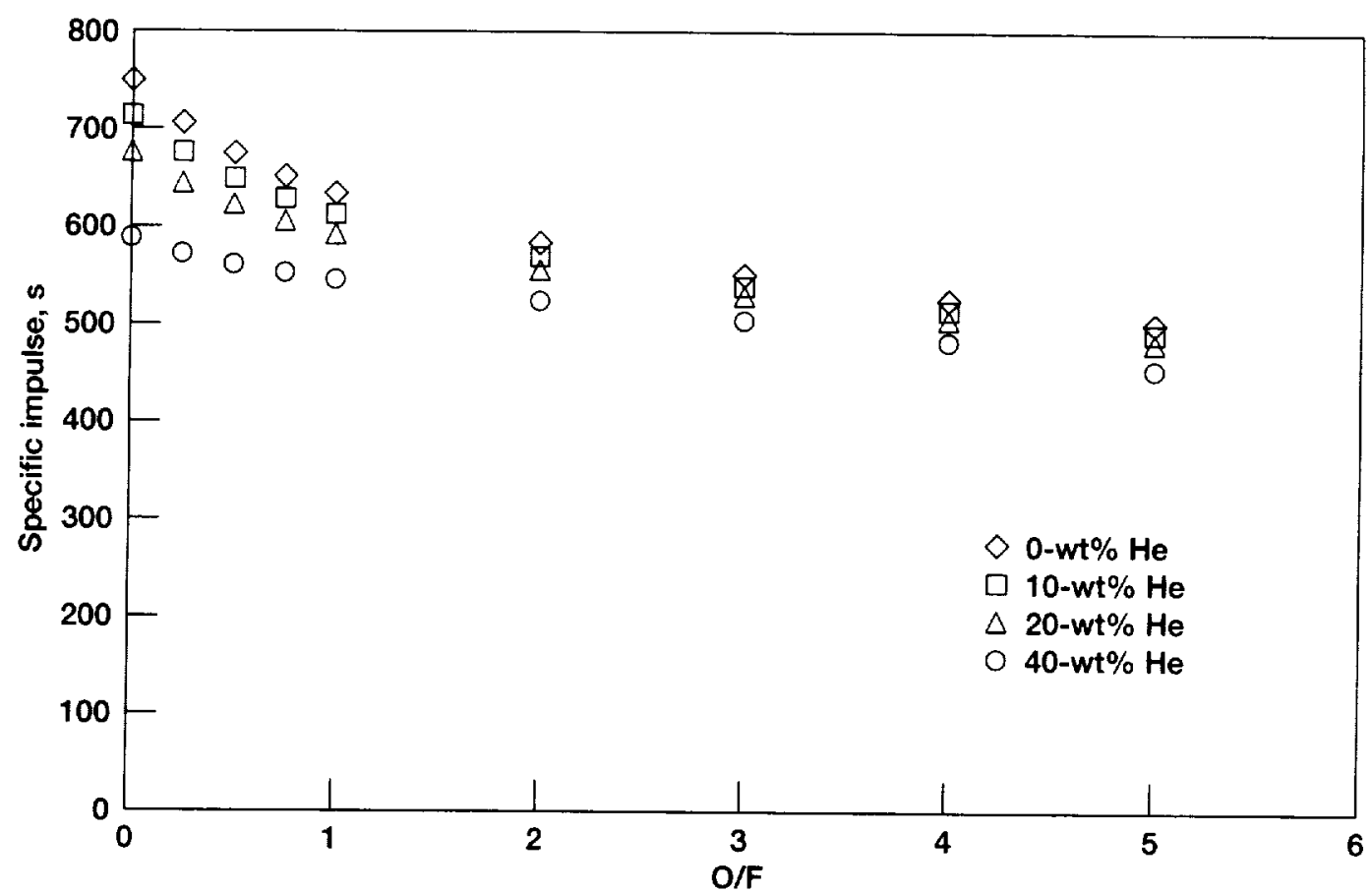

Figure 7.-Atomic hydrogen engine performance: $15-w t \% \mathrm{H}$.

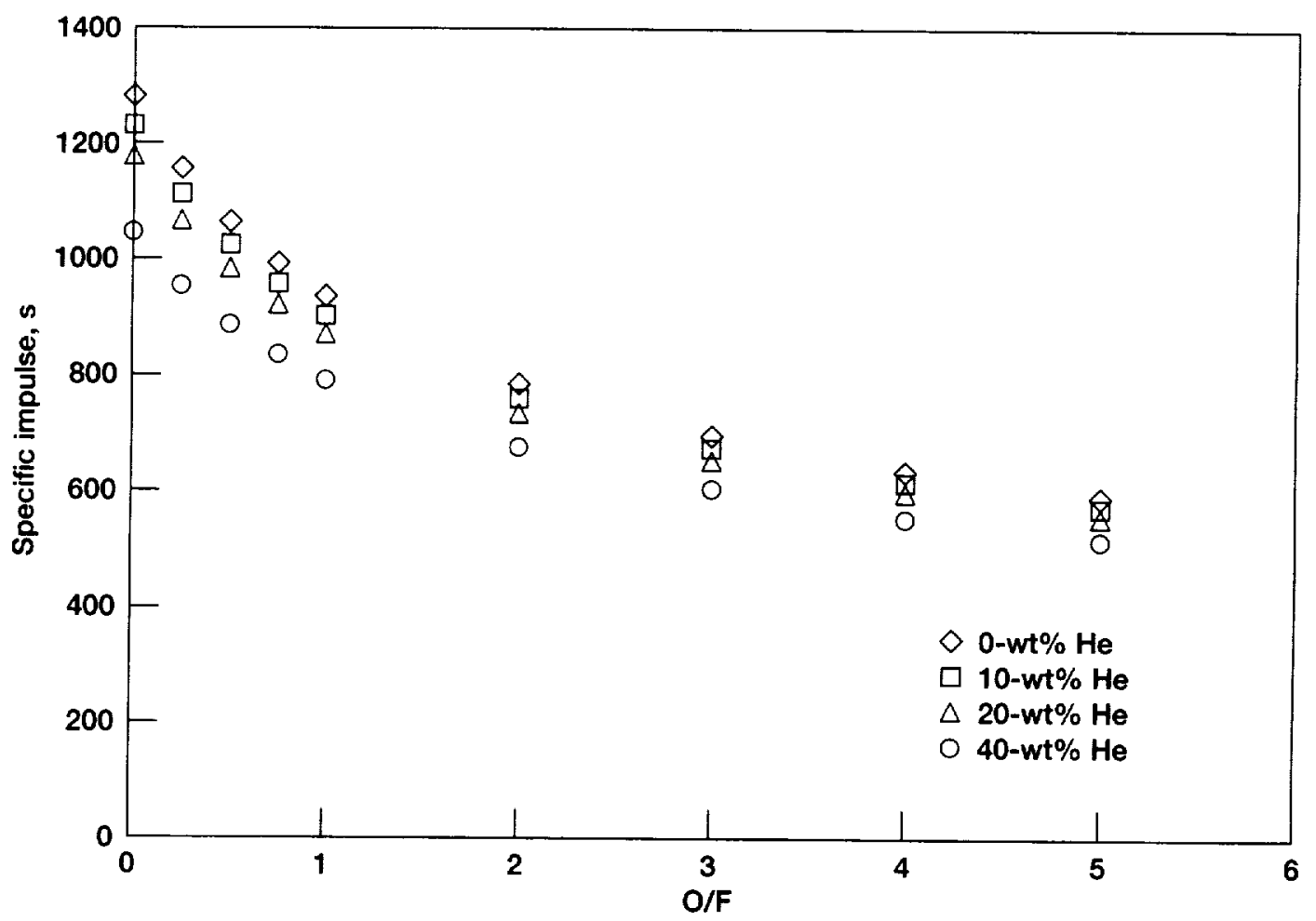

Figure 8.-Atomic hydrogen engine performance: $50-w t \% H$. 


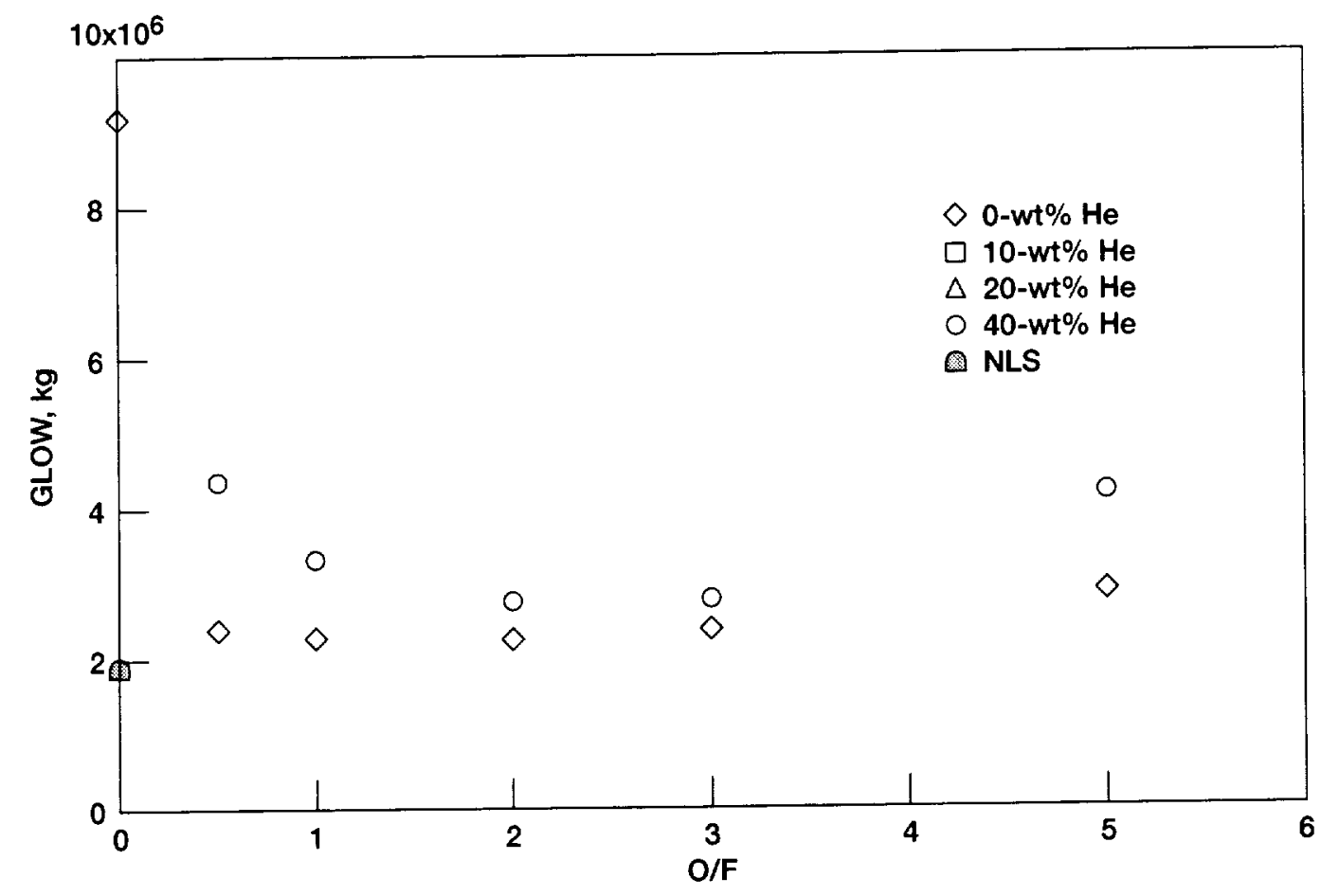

Figure 9.-Atomic boron GLOW: $22-w t \%$ B.

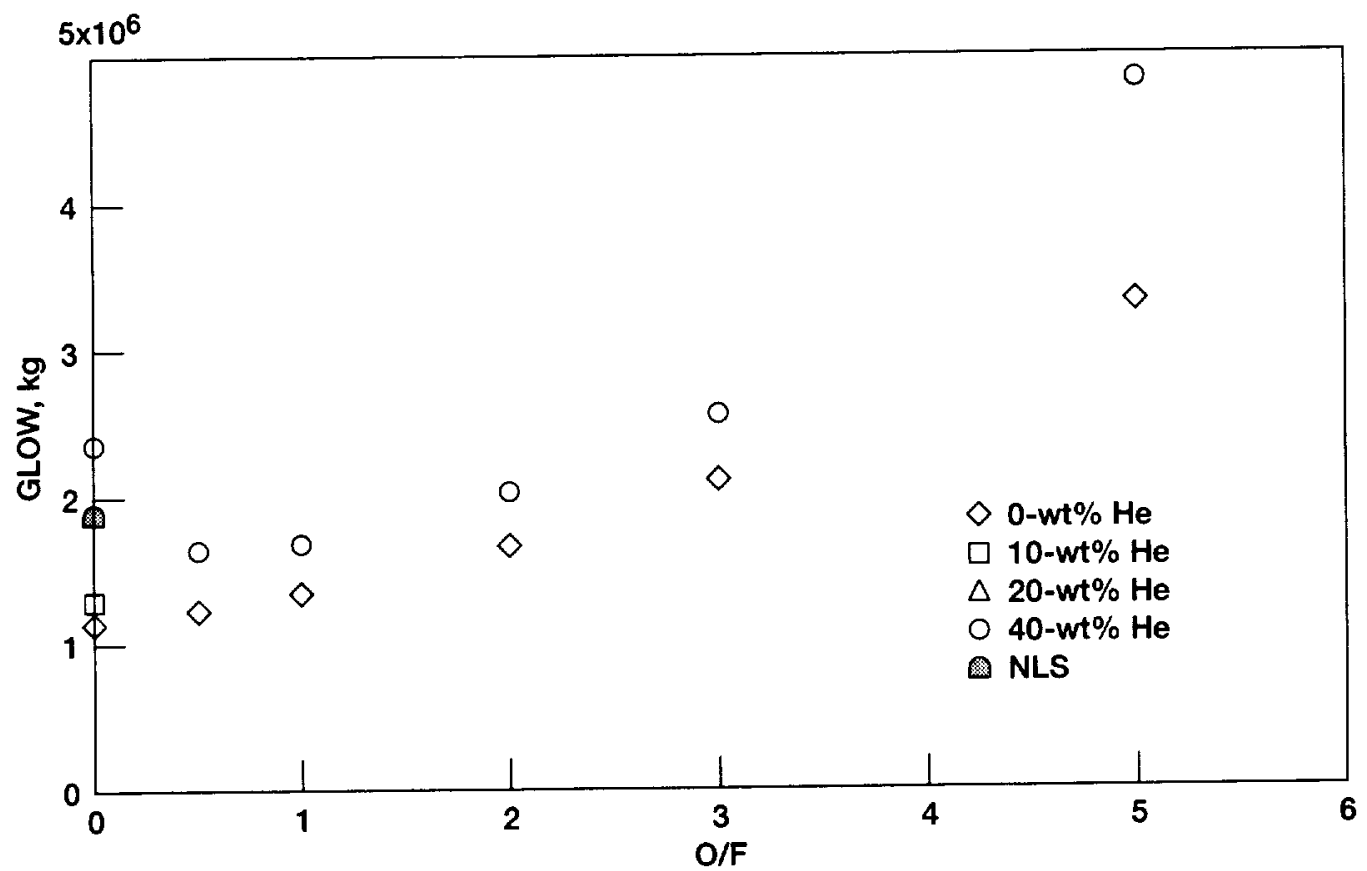

Figure 10.-Atomic boron GLOW: 50-wt\% B. 


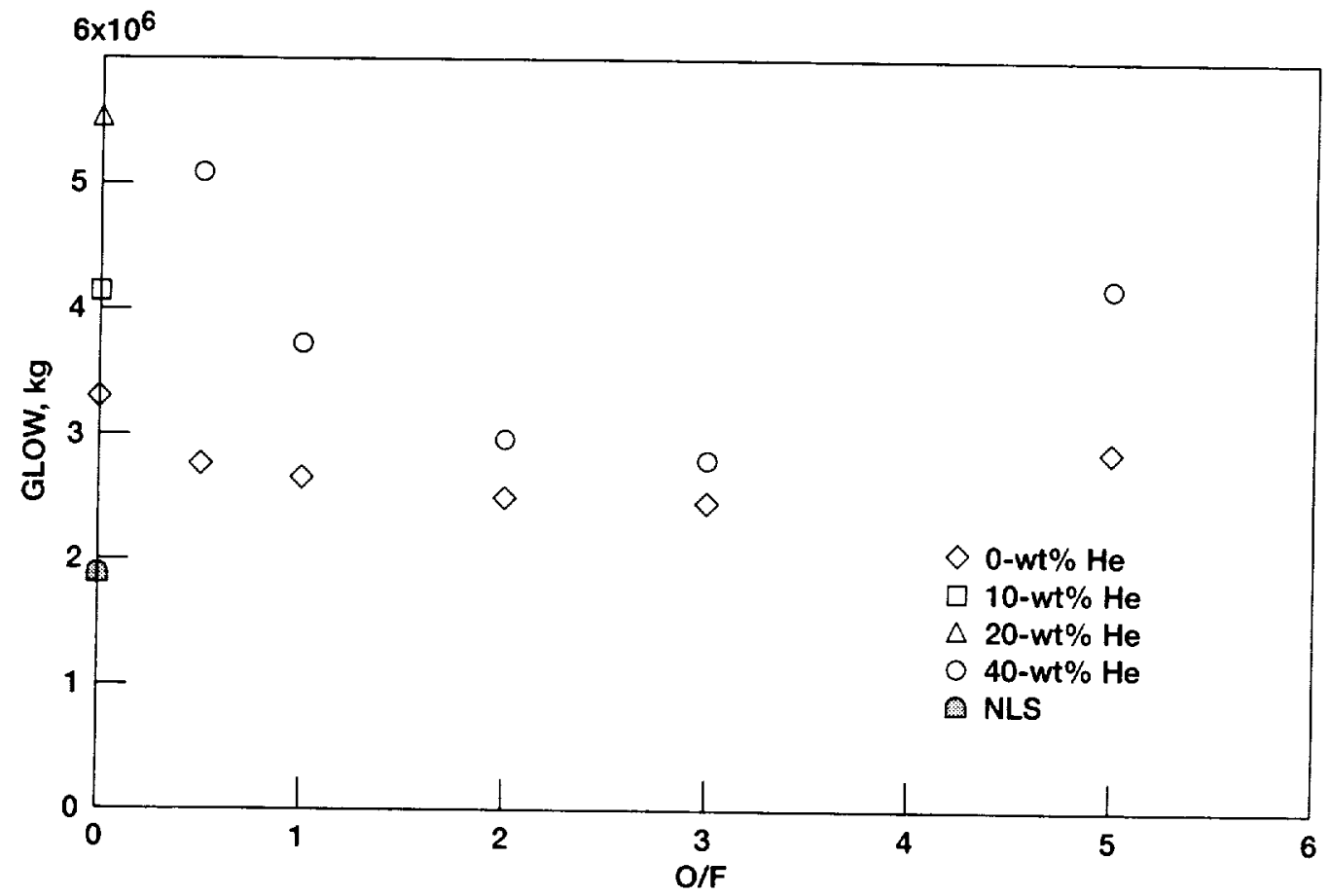

Figure 11.-Atomic carbon GLOW: $24-w t \%$ C.

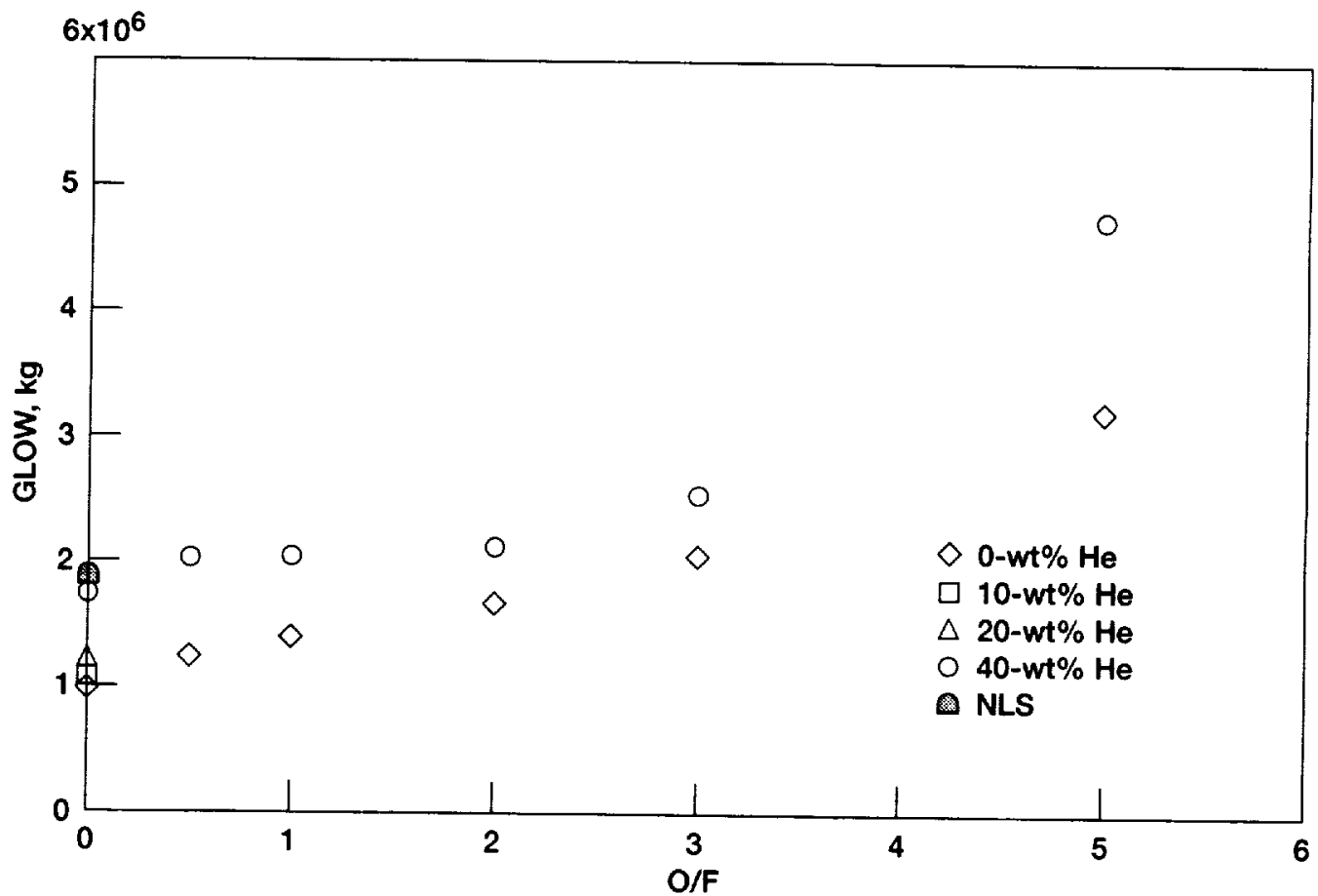

Figure 12.-Atomic carbon GLOW: $50-w t \%$ C. 


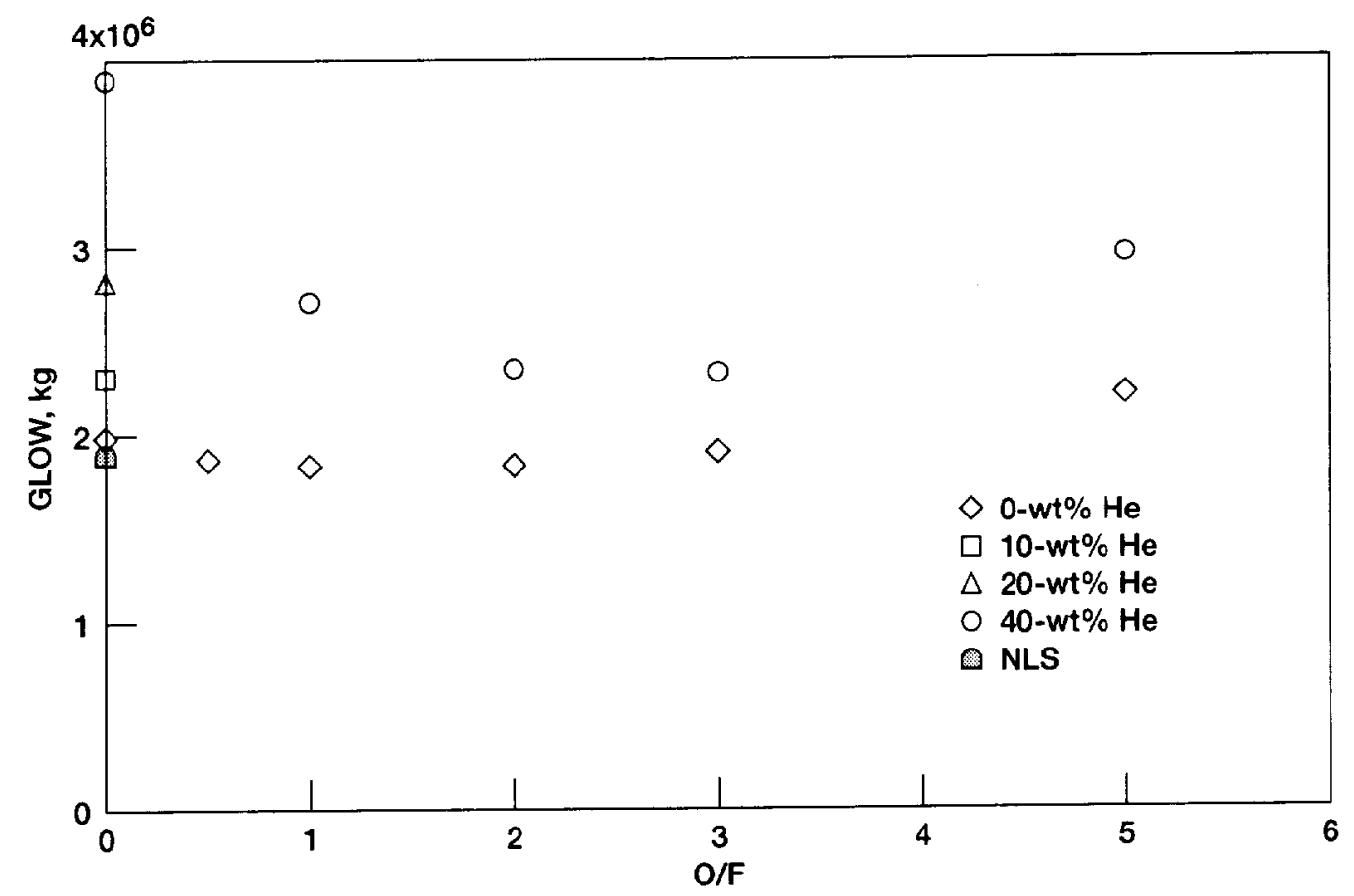

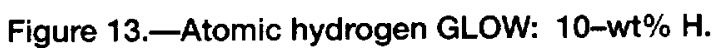

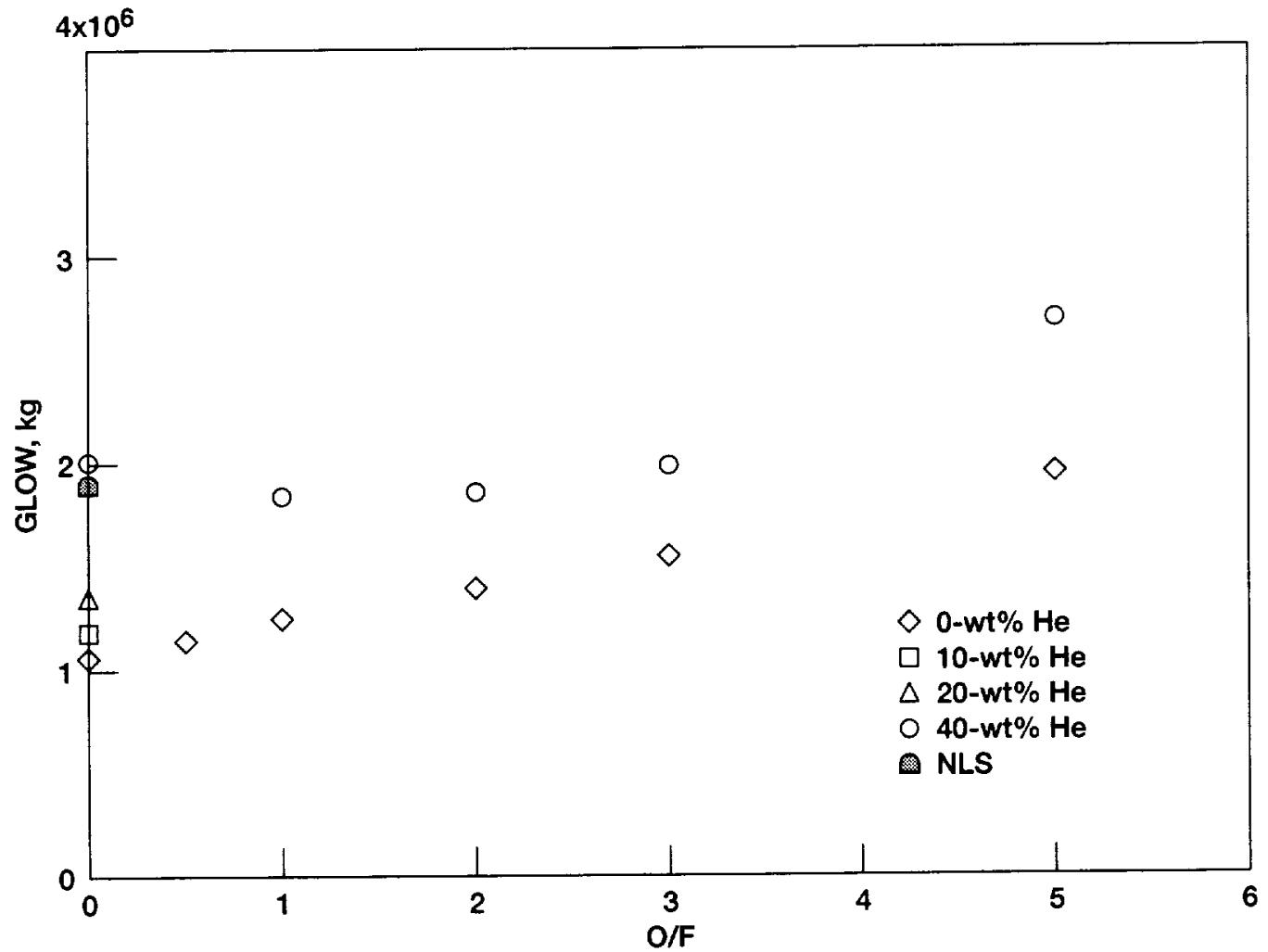

Figure 14.-Atomic hydrogen GLOW: $15-w t \% \mathrm{H}$. 


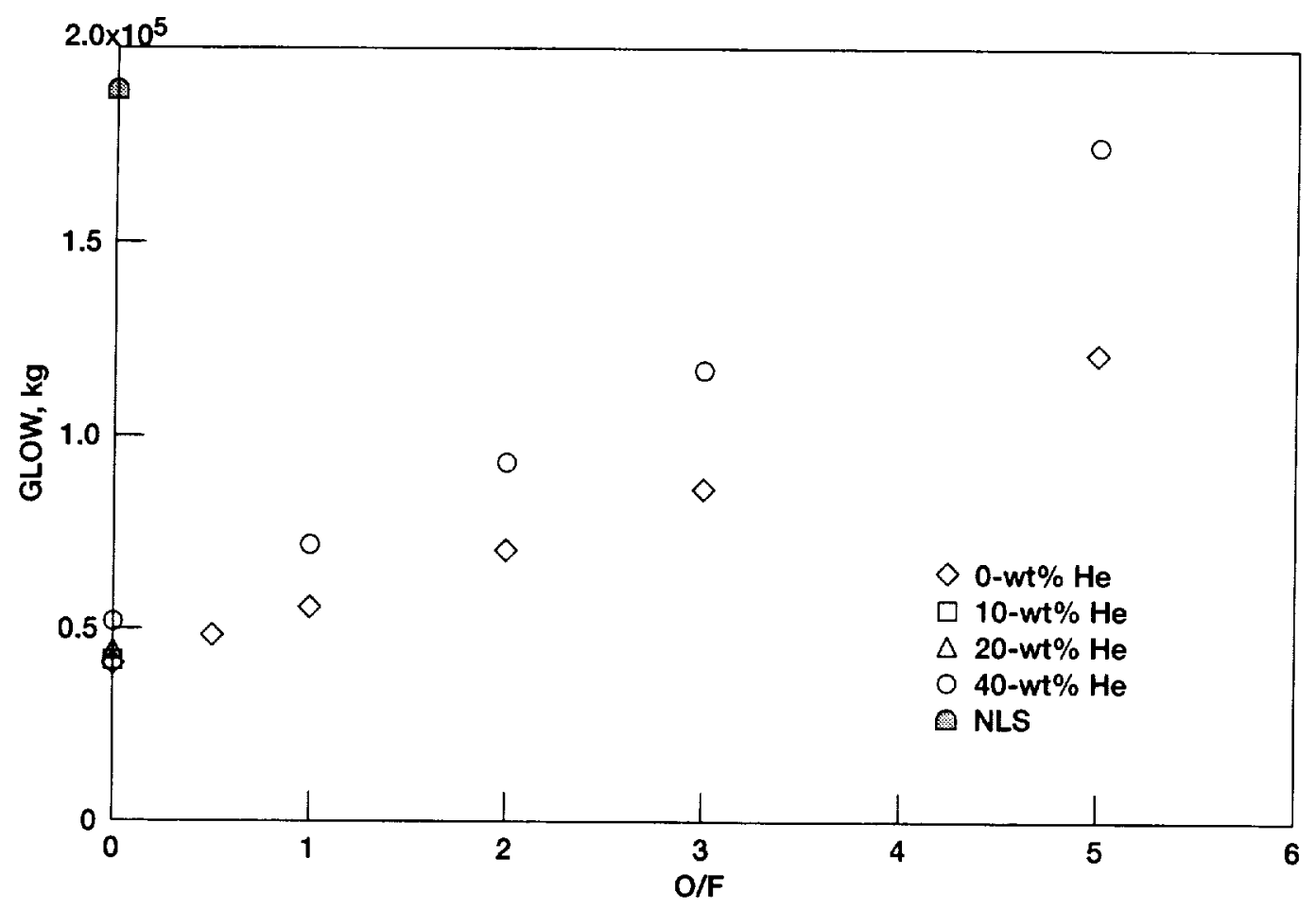

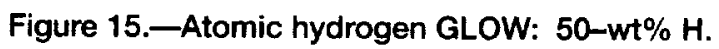

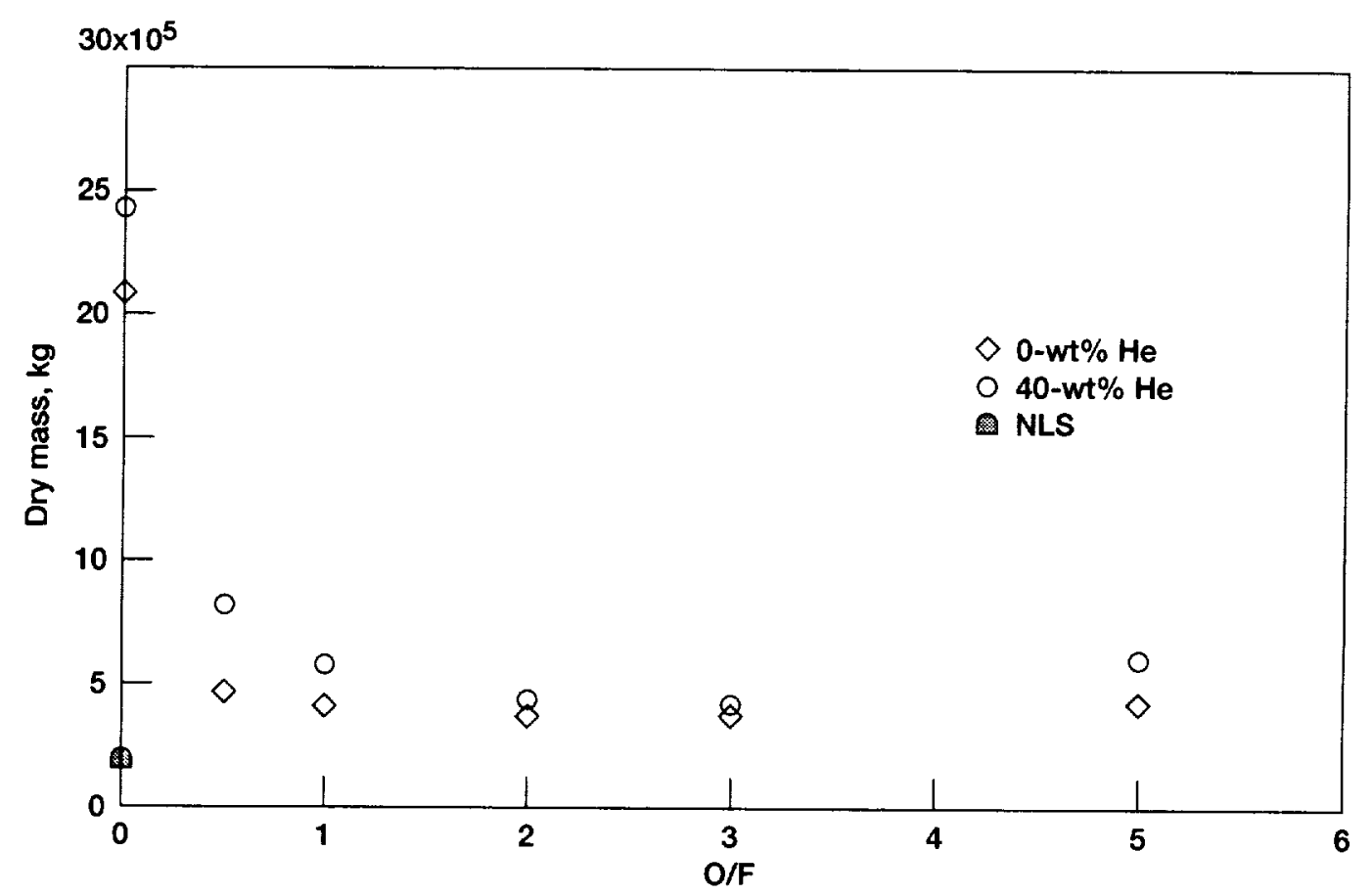

Figure 16.-Atomic boron dry mass: $22-w t \%$ B. 


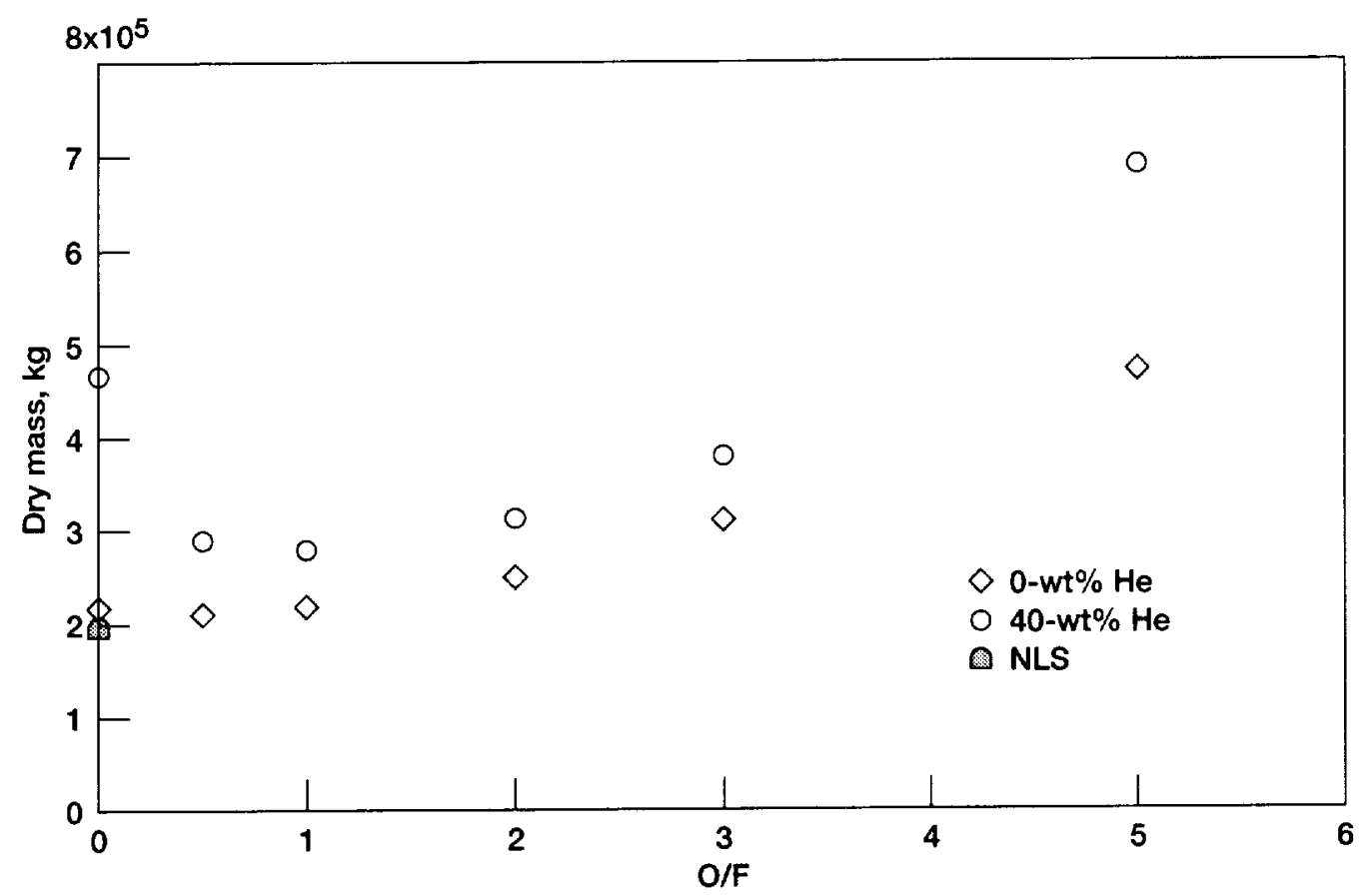

Figure 17.-Atomic boron dry mass: $50-w t \% \mathrm{~B}$.

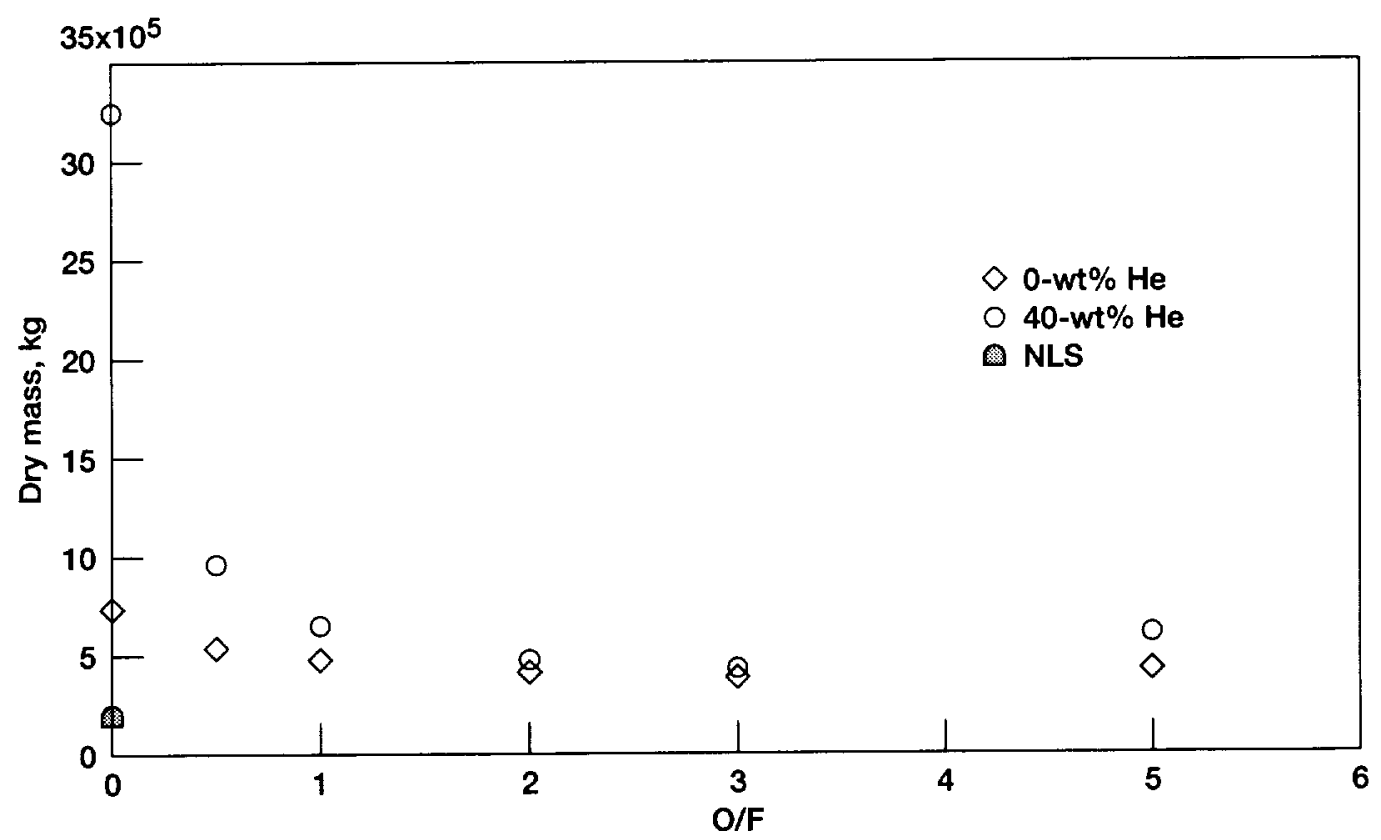

Figure 18.-Atomic carbon GLOW: $24-w t \%$ C. 


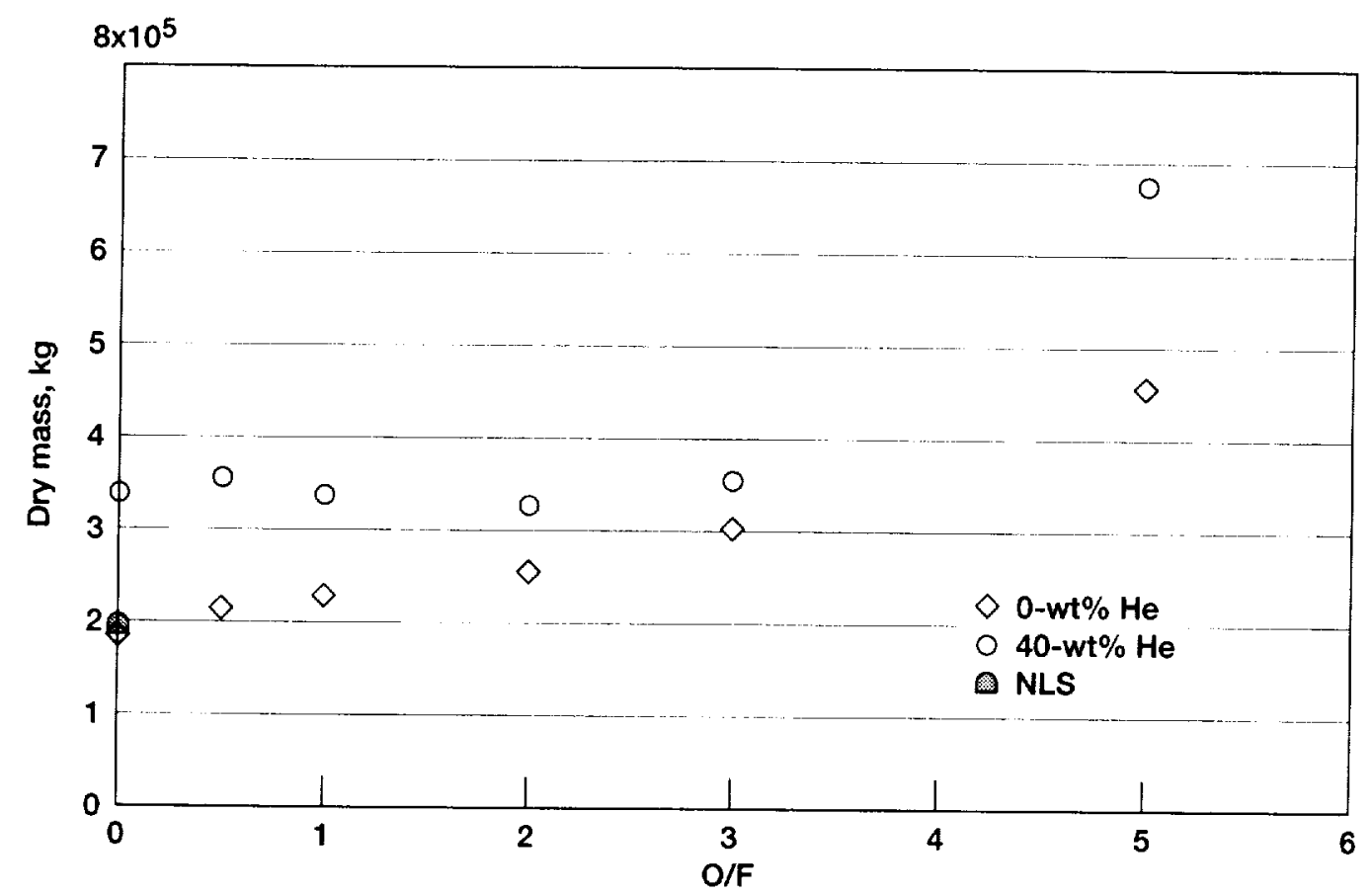

Figure 19.-Atomic carbon dry mass: $50-w+\% \mathrm{C}$.

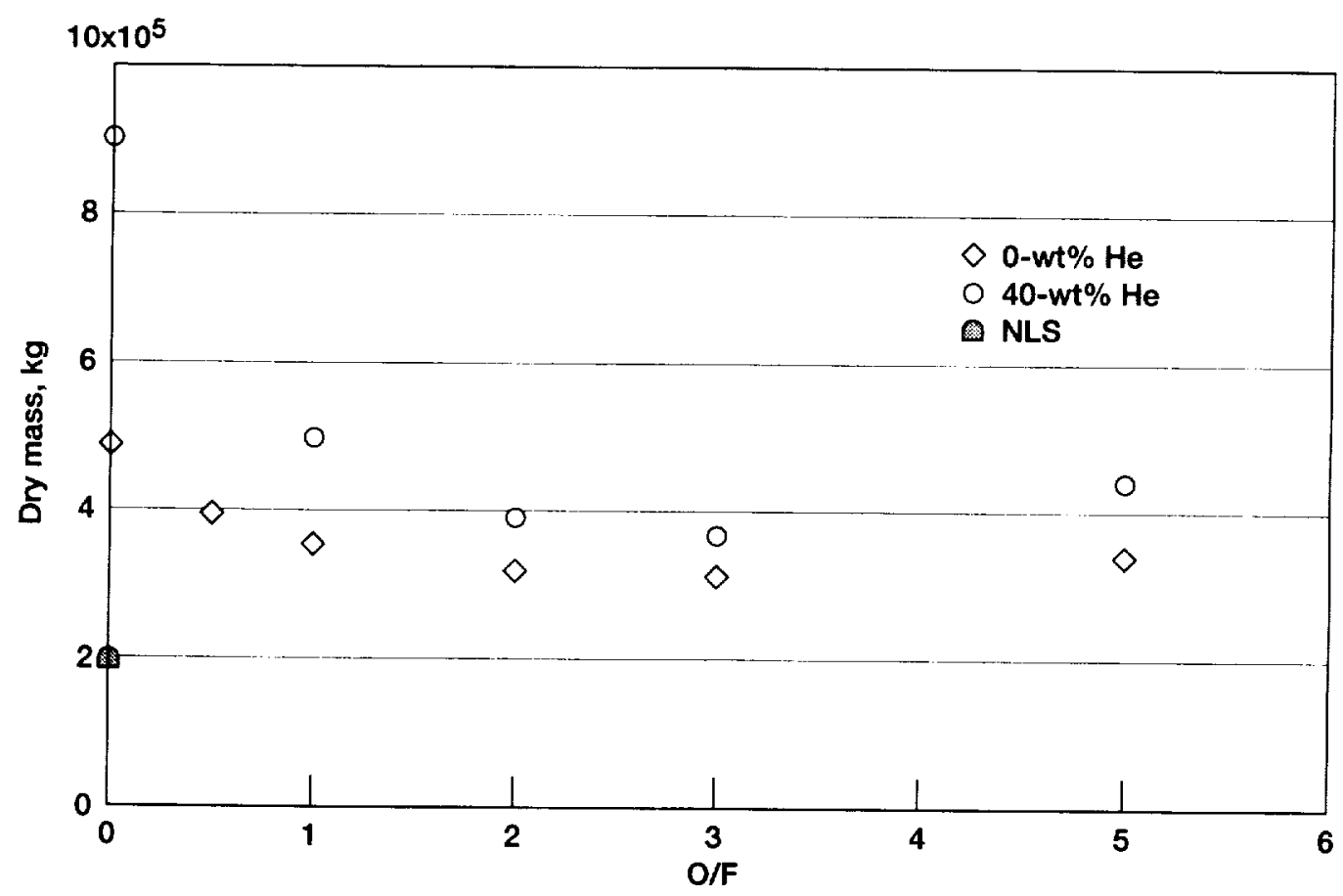

Figure 20.-Atomic hydrogen dry mass: $10-w+\% \mathrm{H}$. 


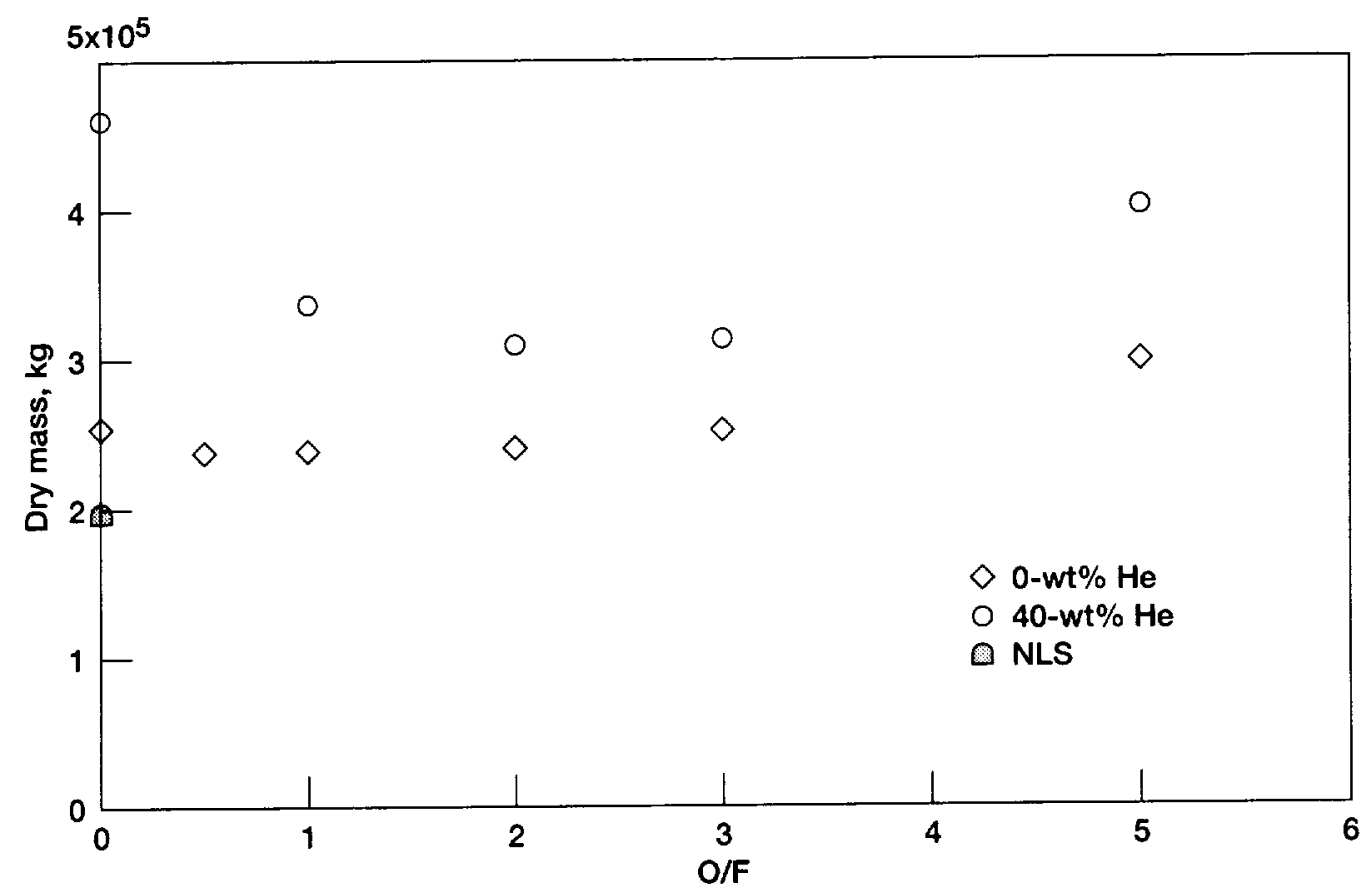

Figure 21.-Atomic hydrogen dry mass: $15-w t \% H$.

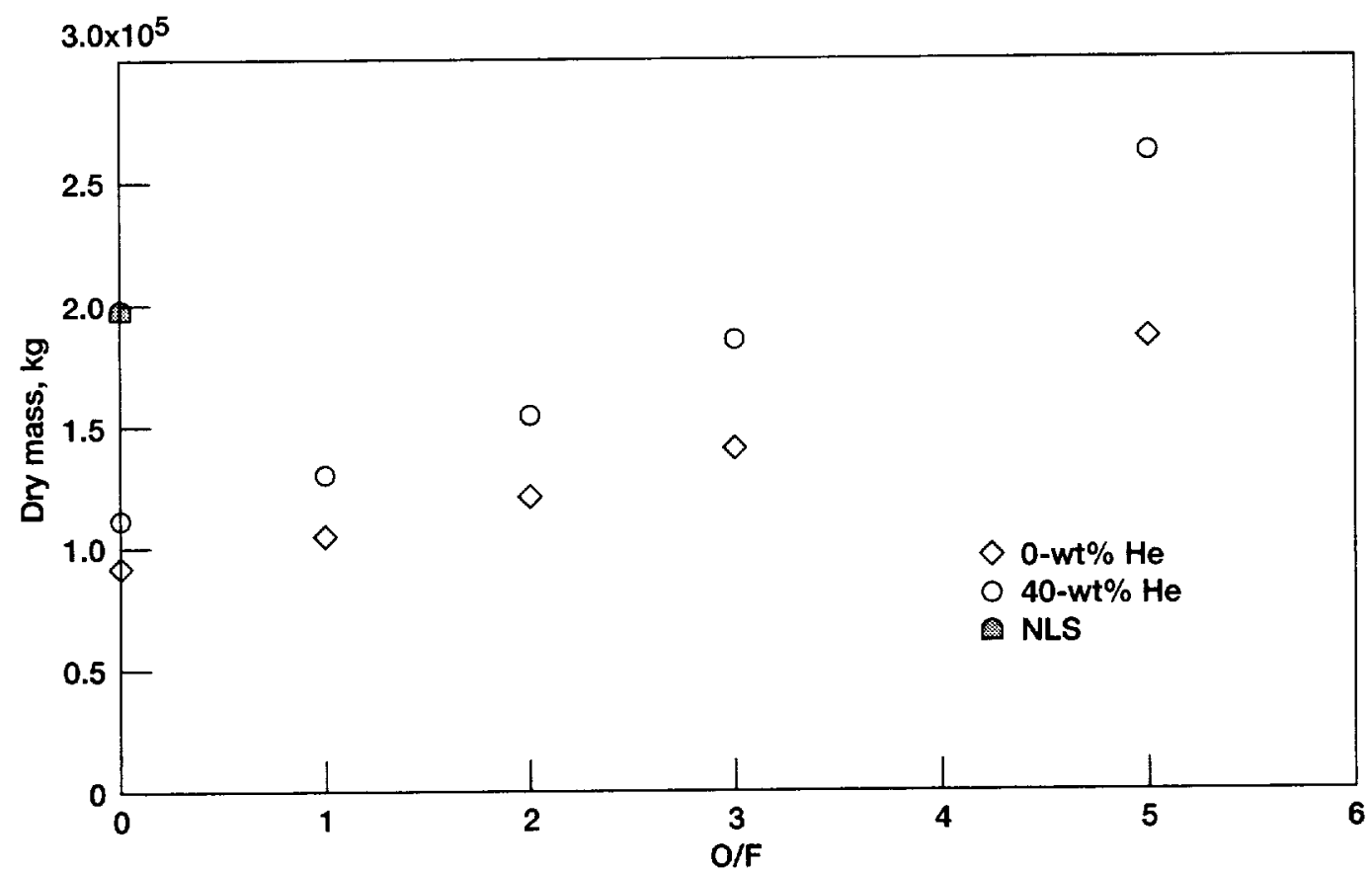

Figure 22.-Atomic hydrogen dry mass: $50-w t \% ~ H$. 
Public reporting burden for this collection of information is estimated to average 1 hour per response, including the time tor reviewing instructions, searching existing data sources, collection of information, including sugestions for reducing and reviewing the collection of intormation. Send comments regarding this burden estimate or any other aspect of this Davis Highway, Suite 1204, Arlington. VA 22202-4302, and to the Office of Mangement and Bud Paper. Directorate lor Information Operations and Reports, 1215 Jeflerson

1. AGENCY USE ONLY (Leave blank) 20503.

\section{TITLE AND SUBTITLE \\ November 2000 \\ Launch Vehicle Performance for Bipropellant Propulsion Using Atomic \\ Propellants With Oxygen}

\section{REPORT TYPE AND DATES COVERED}

Technical Memorandum

\section{AUTHOR(S)}

WU $-713-74-10-00$

Bryan Palaszewski

\section{PERFoRMING ORGANIZATION NAME(S) AND ADdRESS(ES)}

National Aeronautics and Space Administration

John H. Glenn Research Center at Lewis Field

Cleveland, Ohio 44135-3191

\section{SPONSORING/MONITORING AGENCY NAME(S) AND ADDRESS(ES)}

National Aeronautics and Space Administration

Washington, DC 20546-0001
8. PERFORMING ORGANIZATION REPORT NUMBER

E-11927

\section{SUPPLEMENTARY NOTES}

Prepared for the 35th Joint Propulsion Conference and Exhibit cosponsored by the AIAA, ASME, SAE, and ASEE, Los Angeles, California, June 20-24, 1999. Responsible person, Bryan Palaszewski, organization code 5830, 216-977-7493.

Unclassified - Unlimited

Subject Categories: 15, 20 and 28

Distribution: Nonstandard

Available electronically at http://gltrs.grc, nasa.gov/GLTRS

This publication is available from the NASA Center for AeroSpace Information. 301-621-0390.

13. ABSTRACT (Maximum 200 words)

Atomic propellants for bipropellant launch vehicles using atomic boron, carbon, and hydrogen were analyzed. The gross liftoff weights (GLOW) and dry masses of the vehicles were estimated, and the "best" design points for atomic propellants were identified. Engine performance was estimated for a wide range of oxidizer to fuel $(\mathrm{O} / \mathrm{F})$ ratios, atom loadings in the solid hydrogen particles, and amounts of helium carrier fluid. Rocket vehicle GLOW was minimized by operating at an $\mathrm{O} / \mathrm{F}$ ratio of 1.0 to 3.0 for the atomic boron and carbon cases. For the atomic hydrogen cases, a minimum GLOW occurred when using the fuel as a monopropellant $(\mathrm{O} / \mathrm{F}=0.0)$. The atomic vehicle dry masses are also presented, and these data exhibit minimum values at the same or similar $\mathrm{O} / \mathrm{F}$ ratios as those for the vehicle GLOW. A technology assessment of atomic propellants has shown that atomic boron and carbon rocket analyses are considered to be much more near term options than the atomic hydrogen rockets. The technology for storing atomic boron and carbon has shown significant progress, while atomic hydrogen is not able to be stored at the high densities needed for effective propulsion. The GLOW and dry mass data can be used to estimate the cost of future vehicles and their atomic propellant production facilities. The lower the propellant's mass, the lower the overall investment for the specially manufactured atomic propellants.

\section{SUBJECT TERMS}

Systems analysis; Atomic propellants; High energy density propellants; Rocket propulsion; Gelled fuels

\section{SECURITY CLASSIFICATION OF REPORT}

Unclassified

\section{SECURITY CLASSIFICATION OF THIS PAGE Unclassified}

19. SECURITY CLASSIFICATION OF ABSTRACT Unclassified
15. NUMEER OF PAGES

27

16. PRICE CODE $\mathrm{A03}$

20. LIMITATION OF ABSTRACT

Standard Form 298 (Rev. 2-89)

Prescribed by ANSI Std. Z39-18 298.102 


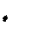


